\title{
Alkaloids as anti-quality factors in plants on western U.S. rangelands
}

\author{
JAMES A. PFISTER, KIP E. PANTER, DALE R. GARDNER, BRYAN L. STEGELMEIER, MICHAEL H. RALPHS, \\ RUSSELL J. MOLYNEUX, AND STEPHEN T. LEE
}

Pfister and Ralphs are rangeland scientists, Panter is a reproductive toxicologist, Gardner and Lee are research chemists, and Stegelmeier is a veterinary pathologist with the USDA-ARS Poisonous Plant Research Laboratory, 1150 E. 1400 N., Logan, Ut. 84341. Molyneux, a research chemist, is with the USDAARS Western Regional Research Center, Albany, Calif. 94710.

\begin{abstract}
Alkaloids constitute the largest class of plant secondary compounds, occurring in 20 to $30 \%$ of perennial herbaceous species in North America. Alkaloid-containing plants are of interest, first because alkaloids often have pronounced physiological reactions when ingested by livestock, and second because alkaloids have distinctive taste characteristics. Thus, alkaloids may kill, injure, or reduce productivity of livestock, and have the potential to directly or indirectly alter diet selection. We review 7 major categories of toxic alkaloids, including pyrrolizidine (e.g., Senecio), quinolizidine (e.g., Lupinus), indolizidine (e.g., Astragalus), diterpenoid (e.g., Delphinium), piperidine (e.g., Conium), pyridine (e.g., Nicotiana), and steroidal (Veratrum-type) alkaloids. Clinically, effects on animal production vary from minimal feed refusal to abortion, birth defects, wasting diseases, agalactia, and death. There are marked species differences in reactions to alkaloids. This has been attributed to rumen metabolism, alkaloid absorption, metabolism, excretion or directly related to their affinity to target tissues such as binding at receptor sites. In spite of alkaloids reputed bitter taste to livestock, some alkaloid-containing plant genera (e.g., Delphinium, Veratrum, Astragalus, Oxytropis, and Lupinus) are often readily ingested by livestock. Management schemes to prevent losses are usually based on recognizing the particular toxic plant, knowing the mechanism of toxicity, and understanding the temporal dynamics of plant alkaloid concentration and consumption by livestock. Once these aforementioned aspects are understood, losses may be reduced by maintaining optimal forage conditions, adjusting grazing pressure and timing of grazing, aversive conditioning, strategic supplementation, changing livestock species, and herbicidal control.
\end{abstract}

Key Words: poisonous plants, plant toxins, forage quality, diet selection, grazing management

Alkaloids are a chemically-diverse group of plant compounds with widely varying biological activities when consumed. Although most effects are thought to be detrimental, many alkaloids have been developed into beneficial drugs and pharmaceuticals. Range plants that contain alkaloids, poison more livestock

Invited paper presented at the symposium "Anti-Quality Factors in Rangeland and Pastureland," Feb. 23-24, 1999, Omaha, Nebraska. Pfister's email: jpfister@cc.usu.edu.

Manuscript accepted 27 Nov. 00

\section{Resumen}

Los alcaloides constituyen la clase mas grande de compuestos secundarios de las plantas y ocurren en un 20 a $30 \%$ de las especies herbáceas perennes de Norte América. Las plantas que contienen alcaloides son de interés, primero porque cuando el ganado consume alcaloides a menudo producen pronunciadas reacciones fisiológicas y segundo porque tienen caracteristicas distintivas de sabor. Así, los alcaloides pueden matar, dañar o reducir la productividad del ganado y tienen el potencial para alterar directa o indirectamente la selección de la dieta. Revisamos 7 categorías principales de alcaloides tóxicos, incluyendo pirrolizidinae (por ejemplo, Senecio), quinolizidina (por ejemplo, Lupinus), indolizidina (por ejemplo, Astragalus), diterpenoide (por ejemplo, Delphinium), piperidina (por ejemplo, Conium), pyridina (por ejemplo, Nicotiana), and esteroidal (tipo Veratrum). Clínicamente, los efectos de los alcaloides sobre la producción animal varían desde el rechazo mínimo del alimento al aborto, defectos de nacimiento, enfermedades mermantes, agalacia y la muerte. Hay marcadas diferencias entre especies en cuanto a las reacciones a los alcaloides. Esto has sido atribuido al metabolismo del rumen, la absorción del alcaloide, el metabolismo, la excreción o directamente relacionado a su afinidad con los tejidos blanco, tal como fijarse en sitios receptores. A pesar de que los alcaloides tiene reputación de ser de sabor amargo para el ganado, algunos géneros de plantas que contienen alcaloides (por ejemplo, Delphinium, Veratrum, Astragalus, Oxytropis y Lupinus) a menudo son ingeridas por el ganado. Los esquemas de manejo para prevenir perdidas usualmente son basados en reconocer una planta tóxica en particular, conociendo el mecanismo de toxicidad y entendiendo las dinámicas temporales de la concentración de alcaloides en la planta y su consumo por el ganado. Una vez los aspectos antes mencionados son entendidos, las perdidas se pueden reducir manteniendo condiciones forrajeras óptimas, ajustando la presión y tiempo de apacentamiento, induciendo un condicionamiento aversivo, utilizando suplementación estratégica, cambiando las especies de ganado y controlando las especies toxicas con herbicidas

worldwide than any other class of toxic compounds. The economic loss to the livestock industry specifically from alkaloidcontaining plants is not known, but livestock losses in cattle and sheep in the western states to all toxic plants are estimated to exceed $\$ 340$ million (Nielsen et al. 1988), not including horses 
Table 1. Direct and indirect economic losses from poisonous plants related to production and off take from domestic livestock and wildlife. Alkaloid-containing plants are responsible for the majority of livestock losses to poisonous plants worldwide.

\begin{tabular}{ll}
\hline \hline Direct losses & Indirect losses \\
\hline Death & Added fencing to restrict access \\
Wasting/reduced weight gains & Herding costs \\
Neurological incapacitation (horses) & Supplemental feeding \\
Abortions & Changes in grazing management \\
Weak/small offspring & Increased veterinary costs for treatment \\
Reduced fertility & Lack of immune response to vaccines \\
Birth defects & Lost opportunity to graze forage \\
Inability to sell/harvest animals & Lost nutrients in ungrazed forages \\
& Reduced land values \\
& Reduced value of grazing permits \\
& Herbicide costs for suppression \\
& Increased risk in overall enterprise \\
\hline
\end{tabular}

and goats. This estimate includes only death and reproductive losses (e.g., abortions), but other indirect costs also impact the livestock industry (Table 1). Our objective is to scrutinize the effects of alkaloid-containing plants on livestock production on western rangelands and outline management solutions. We sequentially review 7 major categories of toxic alkaloids, including pyrrolizidine, quinolizidine, indolizidine, diterpenoid, piperidine, pyridine, and steroidal alkaloids.

\section{Alkaloids-Definition and Distribution}

Alkaloids are difficult to define because of their diversity, but the alkaloid chemist S.W. Pelletier (1983) defined alkaloids as "a cyclic organic compound containing nitrogen..." The presence of a nitrogen atom usually makes alkaloids basic, as suggested by their name. Alkaloids are classified by their heterocylic ring structure and the location of the nitrogen atom in the ring. Ring structure is important

\section{Do Alkaloids Alter Diet Selection?}

Alkaloids are reported to taste bitter (Bate-Smith 1972). Garcia and Hankins (1975) argued that animals acquire natural aversions to most alkaloids because bitter taste is often linked with toxicity. Some forage plants such as reed canarygrass (Phalaris arundinaceae L.) and certain lupines (Lupinus spp.) are unpalatable because of high alkaloid concentrations (Ralphs and Olsen 1987). Nonetheless, Robinson (1979) and Glendinning (1994) concluded that alkaloids are not universally repellent to herbivores. Additionally, Molyneux and Ralphs (1992) suggest that some toxic alkaloids are not bitter tasting to livestock. Sheep (Arnold and Hill 1972), cattle (Pfister et al. 1996a, Panter et al. 1997), and pigs (Panter et al. 1985) do not necessarily avoid bitter tastes, nor do sheep form stronger aversions to bitter than to sweet flavors (Launchbaugh et al. 1993). As a rule, grazing animals are not deterred by the supposed bitterness of alkaloid-containing plants. Intake of alkaloid-containing plants is primarily regulated by positive or negative postingestive consequences (see Launchbaugh et al. this volume).

\section{Indolizidine alkaloids} with significant (>0.05\% of dry weight) alkaloid concentration is Liliaceae (Robinson 1979). Obviously, this statement ignores alkaloids in monocots produced by fungal endophytes (see Thompson et al. this volume). The major alkaloid-containing plants on western ranges are classified by the type of alkaloid they contain (Table 2).

Table 2. Major classes of plant alkaloids, livestock species primarily affected, body system(s) affected, and major plant genera containing the alkaloids.

\begin{tabular}{|c|c|c|c|c|}
\hline \multirow[t]{2}{*}{ Type of Alkaloid } & \multirow{2}{*}{$\begin{array}{l}\text { Animal Species } \\
\text { Primarily Affected }\end{array}$} & \multirow[t]{2}{*}{ Body System(s) Affected } & \multicolumn{2}{|c|}{ Plants Containing Toxin } \\
\hline & & & Common name & Scientific name \\
\hline Diterpene & Cattle & Muscle paralysis & larkspur & Delphinium species \\
\hline Pyrrolizidine & Cattle, horses & Liver toxin; photosensitization & $\begin{array}{l}\text { groundsel } \\
\text { houndstongue }\end{array}$ & $\begin{array}{l}\text { Senecio species } \\
\text { Cynoglossum officinale }\end{array}$ \\
\hline Steroidal (solanum type) & Cattle, sheep, horses & $\mathrm{CNS}^{1}$ toxin; digestive tract & nightshades & Solanum species \\
\hline Steroidal (veratrum type) & Sheep & Birth defects; lung congestion & $\begin{array}{l}\text { skunk cabbage } \\
\text { death camas }\end{array}$ & $\begin{array}{l}\text { Veratrum species } \\
\text { Zigadenus } \text { species }\end{array}$ \\
\hline Piperidine & Cattle, sheep, horses, pigs & CNS toxin; birth defects & $\begin{array}{l}\text { poison hemlock } \\
\text { lupine } \\
\text { tobacco }\end{array}$ & $\begin{array}{l}\text { Conium maculatum } \\
\text { Lupinus species } \\
\text { Nicotiana species }\end{array}$ \\
\hline Quinolizidine & Cattle, sheep, horses & Respiratory paralysis;birth defects & lupine & Lupinus species \\
\hline Indolizidine & Horses, cattle, sheep & Digestive, reproductive \& CNS & locoweed & Astragalus and Oxytropis spp. \\
\hline Pyridine & Cattle, horses, pigs, sheep & CNS toxin; birth defects & tobacco & Nicotiana species \\
\hline
\end{tabular}


Table 3. Major locoweed species containing indolizidine alkaloids, primary distribution in the western U.S., and range of swainsonine concentration (mg/g dry weight).

\begin{tabular}{|c|c|c|c|}
\hline Scientific name ${ }^{1}$ & Common name & Distribution & $\begin{array}{l}\text { Range in } \\
\text { Concentration }\end{array}$ \\
\hline Astragalus & & & ----(mg/g)---- \\
\hline allochrous & rattleweed & southern California east to Texas & 0.7 to $11.5^{2,3}$ \\
\hline bisulcatus & two-grooved milkvetch & southern Canada south to New Mexico & 0.0 to $0.4^{2,3}$ \\
\hline drummondii & Drummond milkvetch & southern Canada south to northern N.M. & $0.60^{3}$ \\
\hline emoryanus & red-stemmed peavine & Utah and southwestern states into Texas & 0.5 to $1^{4}$ \\
\hline lentiginosus & freckled milkvetch & $\begin{array}{l}\text { western Canada to California; Rocky } \\
\text { Mountains south into Arizona to Texas }\end{array}$ & 0.05 to $0.4^{3,6,7}$ \\
\hline lonchocarpus & great rushy milkvetch & $\begin{array}{l}\text { Nevada, Utah, Colorado, and southwestern } \\
\text { states }\end{array}$ & 0.0 to $4.4^{2,3,5}$ \\
\hline missouriensis & Missouri milkvetch & $\begin{array}{l}\text { southern Canada south to New Mexico } \\
\text { and Texas }\end{array}$ & 0.12 to $0.18^{2,3}$ \\
\hline mollissimus & woolly locoweed & Utah and Wyoming south to Mexico & 0.02 to $10.3^{2,4,5,6}$ \\
\hline praelongus & stinking milkvetch & $\begin{array}{l}\text { Utah, Nevada, Colorado and southwestern } \\
\text { states east into Texas }\end{array}$ & 0.03 to $0.2^{2,3,5}$ \\
\hline tephrodes & ashen milkvetch & $\begin{array}{l}\text { Nevada, southwestern Utah and New Mexico, } \\
\text { Arizona, and California }\end{array}$ & 0.0 to $0.9^{2,3}$ \\
\hline \multicolumn{4}{|l|}{ Oxytropis } \\
\hline lambertii & Lambert's locoweed & $\begin{array}{l}\text { southern Canada south to Arizona and } \\
\text { New Mexico }\end{array}$ & 0.2 to $1.0^{2,5}$ \\
\hline sericea & whitepoint locoweed & $\begin{array}{l}\text { northwest Canada south to Nevada, New } \\
\text { Mexico and Oklahoma }\end{array}$ & 0.05 to $1.2^{3,5,7}$ \\
\hline
\end{tabular}

\footnotetext{
${ }^{2}$ Smith et al. 1992

${ }^{3}$ Fox et al. 1998

${ }_{5}^{4}$ Davis et al. 1984

${ }^{5}$ R.J. Molyneux, personal communication

${ }^{6}$ D.R. Gardner, personal communication

${ }^{7}$ Molyneux et al. 1989
}

Many species have one or several varieties, but that level of detail is beyond the scope of this paper

Oxytropis species have been found to contain swainsonine (Table 3). Many of these toxic species are located around the Colorado Plateau, the Great Basin, and portions of the Great Plains. Some Astragalus species contain nitro-toxins (e.g., Astragalus miser Dougl. ex Hook; see Majak and Benn, this volume) or selenium (e.g., Astragalus bisulcatus (Hook.) Gray). Other genera worldwide contain swainsonine, including Swainsona spp. (Colegate and Dorling 1997) and Ipomoea (Molyneux et al. 1995). Within the U.S., Ipomoea spp. (morning glory) have not been examined for swainsonine, but Ipomoea batatas (L.) Lam. (sweet potato) can be toxic to livestock through an unrelated mechanism.

\section{Mechanism of Intoxication}

Swainsonine has a chemical structure similar to mannose and glucose, and this similarity may be the basis of its toxicity (Colegate et al. 1989). Swainsonine inhibits several intracellular mannosidase enzymes responsible for cleaving sugar molecules from oligosaccharides (Broquist 1986). Inhibition of $\propto$-mannosidase and subsequent failure to trim mannose from oligosaccharides, results in accumulation of mannose-rich oligosaccharides in lysosomes and causes cellular disruption, and eventual cell death (Dorling et al. 1989,
Elbein 1989). These accumulated oligosaccharides damage cells in thyroid, brain, pancreas, and kidney tissue, characterized as foamy cytoplasmic vacuolation (Van Kampen and James 1970, Stegelmeier et al. 1995a). Inhibition of Golgi mannosidase II results in abnormal glycosylation of proteins, affecting hormones, membrane receptors, and enzymes throughout the body. Once a sufficient number of cells are damaged, signs of poisoning are seen, which may occur within 3 weeks (Van Kampen and James 1970). Microscopically, damage in the CNS results from vacuolar degeneration of both neurons and glia (Stegelmeier et al. 1994). Pathological lesions appear within 1 week after locoweed feeding begins (Van Kampen and James 1970), and when locoweed feeding ceases, the cytoplasmic vacuoles disappear quickly (James and Van Kampen 1971). Residual CNS lesions may resolve quickly depending on the extent of intoxication (Pfister et al. 1996b), but once a particular threshold is exceeded, CNS damage becomes permanent (James and Van Kampen 1971), and the animal likely will display long-term abnormal behavior (Pfister et al. 1996b).

There appears to be a dose-response threshold for swainsonine, such that incomplete enzyme inhibition occurs at lower doses. Doses at or above the thresh- old result in similar etiology and further increases in dosage do not increase the severity of intoxication (Stegelmeier et al. 1995a); however, this threshold is low and relatively small doses have been shown to produce both clinical and histologic lesions. For example, sheep were intoxicated with average daily swainsonine doses of $0.21 \mathrm{mg} / \mathrm{kg}$ body weight/day (as ingested plant material, Pfister et al. 1996b).

Swainsonine is water-soluble, and is rapidly excreted (Stegelmeier et al. $1995 b)$. Clearance time $\left(T_{1 / 2}\right)$ for swainsonine from most tissues is about 20 hours; however, for the liver and kidneys it is much longer and requires about 60 hours. Swainsonine is distributed throughout all tissues and is present in many animal products. Thus, current recommendations are that animal products not be used, and intoxicated animals withheld from slaughter for about 8 days after animals discontinue locoweed ingestion $\left(\mathrm{T}_{1 / 2} \mathrm{x}\right.$ 10; Stegelmeier et al. 1998a). Lactating animals that eat locoweed will excrete swainsonine into the milk within $30 \mathrm{~min}$ (Broquist 1986); therefore nursing young may become intoxicated (James and Hartley 1977).

\section{Clinical Signs}

The symptoms of locoweed poisoning are lethargy, muscular incoordination, 
intention tremors, nervousness, and excitability, progressing to emaciation, possible maniacal behavior when stressed, and death. Horses may be particularly susceptible to intoxication (James and Van Kampen 1971) and may be dangerous when handled. Abortions and water belly (i.e., hydrops amnii) often occur when pregnant animals eat locoweed (Ralphs et al. 1994b). If the fetus survives in utero intoxication, the newborn offspring often exhibits abnormal suckling behavior, and may not survive (Pfister et al. 1993). Grazing animals that consume locoweeds at higher elevations (e.g., > $2200 \mathrm{~m}$ ) are increasingly susceptible to congestive right heart failure (James et al. 1983).

Locoweed poisoning may be diagnosed by determining if animals have been exposed to locoweed, and by evaluating clinical and pathological signs; affected animals show typical overt signs of poisoning while living, and have pathological lesions upon post-mortem examination. With living animals, definitive diagnostic tests using serum can verify consumption of locoweed (Stegelmeier et al. 1995b). Serum tests are not very reliable, however, if suspected animals have not recently (i.e., within 2-3 days) been eating locoweed, as serum swainsonine quickly disappears, and enzyme concentrations quickly return to normal ranges. Future work will determine if other diagnostic assays, such as determining glycosylation of specific proteins, may be better indicators of intoxication.

\section{Effects on Livestock Nutrition and Grazing Behavior}

A dominant feature of locoweed poisoning in livestock is gradual emaciation (i.e., wasting, Marsh 1909), which may not cease when animals are removed from locoweed (James et al. 1969). In studies at our laboratory, rats, sheep, cattle, and horses have all shown declines in food intake and body condition while eating locoweed, and the wasting continued after locoweed feeding ceased. Steers lost weight while grazing locoweed, and gains did not resume for 45-60 days after locoweed feeding ceased (Ralphs et al. 2000). Overtly intoxicated horses, when removed from locoweed-infested pastures, continued to decline in body condition over 4 weeks even though their appetites did not diminish (Pfister unpublished data). The loss of productive function may result directly from neurological damage because of impaired ability to prehend and masticate food (Ralphs et al. 1991b). Ralphs et al. (1991b) reported that sheep had seizures that severely disrupted prehension and mastication. The loss of body condition may also be a direct result of swainsonine on hormonal and digestive functions (Stegelmeier et al. 1995a). Both aspects probably operate simultaneously to cause weight loss, because weight loss is not fully attributable to lower food intake (Velastegui et al. 1992).

Mildly or moderately intoxicated animals can be salvaged and returned to near normalcy by removing them from locoweed, and offering supplements (Marsh 1909). This does not ensure that such animals will be fully productive and normal, but they may regain sufficient body weight to allow resale (Torell et al. 1999b). Notwithstanding, severely intoxicated animals may not regain lost body weight even with supplemental feeding, and will never be productive no matter how intensive the rehabilitation.

There are pervasive anecdotal accounts of addiction or of animals "seeking out" locoweed in preference to other desirable forage. Marsh (1909) reported that locoweed was addictive to various animals, including mules, pigs and pronghorn antelope. Lewin (1931) described livestock addiction to locoweed and to the Australian plant Swainsona, long before it was known that Swainsona and locoweed contained the same toxin. Recent reports of toxicity in South America (Peru and Brazil) from morning glory vines (Ipomoea spp.) indicate that livestock become addicted or dependent on these plants (Molyneux, personal communication; Tokarnia et al. 1992). Ralphs et al. (1990) reported that dried, ground whitepoint locoweed (Oxytropis sericea Nutt. in T. \& G.) was not addictive, but some animals habituated or become accustomed to eating the plant material. The obsessive consumption that producers observe may result from locoweed being relatively more palatable than associated forage (Ralphs et al. 1993), or alternatively, locoweed may have pharmacological properties that are reinforcing (Pfister 1999).

\section{Management and Control}

Swainsonine usually occurs at very low concentrations $(0.01$ to $0.3 \%$ of dry weight) in locoweeds (Table 3), with much of the toxin found in the seeds. Fluctuations in swainsonine concentration as the plants mature have little effect on how much locoweed is eaten (Ralphs and Molyneux 1989). The growth habits of locoweed in relation to other available forages generally determine if and how much of the plant is eaten. Livestock producers should not over-stock or over-utilize locoweed-infested ranges, and should manage for sufficient desirable forage so that grazing pressure does not impel livestock to begin eating locoweed. When animals become overtly intoxicated, the most economical solution may be to remove them from pasture, and allow time for recovery before selling (Torell et al. 1999b).

\section{Whitepoint locoweed (Oxytropis sericea)}

Whitepoint locoweed begins growth in late winter and early spring on shortgrass prairie rangelands, and the green leaves are often more palatable than are dormant grasses. Livestock readily consume green locoweed leaves during the spring when cool-season grasses are just beginning growth, and warm-season grasses are dormant (Ralphs et al. 1993). Grazing of whitepoint locoweed may cease when warm season grasses begin active growth in early summer (Ralphs et al. 1993), or livestock may switch diet selection to other green locoweeds (Oxytropis lambertii Pursh, Ralphs unpublished data), if available. On mountain rangelands, cattle prefer immature seed pods of whitepoint locoweed, but may also eat mature pods and green leaves later in the summer, particularly if grazing pressure is excessive. (Ralphs 1987). In contrast to shortgrass prairie rangelands, whitepoint locoweed on high elevation rangelands is grazed during summer even though other forage is also green and actively growing (Ralphs et al. 1986, Ralphs et al. 1987, Ralphs 1987). Simple changes in grazing management can have profound positive impacts on losses to whitepoint locoweed. For example, Ralphs et al. (1984) reported reductions in cattle losses from over $20 \%$ to less than $3 \%$ annually from a simple change in grazing management.

\section{Specklepod locoweed (Astragalus} lentiginosus Dougl. ex Hook.)

Limited studies with cattle and horses (Pfister unpublished data) suggest that, during spring, likelihood of animals eating locoweed increases greatly when animals begin to search avidly for newly growing cool-season grasses (i.e., "chasing green"). Cattle prefer dormant grasses to specklepod locoweed (var. diphysus) during much of the spring, but once cattle begin eagerly selecting green grass, they also begin eating still-green, but drying, locoweed. During winter, cattle will even eat toxic black stems from previous growing seasons (Ralphs et al. 1988). During spring, horses intensely search for green grass, 
Table 4. Characteristics, relative toxicity, and general concentration range of toxic alkaloids of the dominant larkspur species in the western U.S.

\begin{tabular}{|c|c|c|c|c|c|}
\hline Class/Species & $\begin{array}{l}\text { Typical height } \\
\text { at maturity }\end{array}$ & Elevation & $\begin{array}{l}\text { Associated plant } \\
\text { communities }\end{array}$ & $\begin{array}{l}\text { Typical } \\
\text { risk of losses }\end{array}$ & $\begin{array}{l}\text { Alkaloid } \\
\text { concentration }^{2}\end{array}$ \\
\hline \multicolumn{6}{|l|}{ Tall Larkspurs } \\
\hline D. barbeyi & $90-180$ & $>2200$ & $\begin{array}{l}\text { aspen, conifers, alpine meadow, } \\
\text { mountain brush, alpine tundra }\end{array}$ & moderate to severe & $1-29$ \\
\hline D. glaucescens & $76-90$ & $>2000$ & mountain meadows, sagebrush & low to moderate & $1-12$ \\
\hline D. occidentale & $90-180$ & $>2000$ & $\begin{array}{l}\text { mountain brush, sagebrush, } \\
\text { conifer, aspen }\end{array}$ & low to severe & $0-18$ \\
\hline \multicolumn{6}{|l|}{ Low Larkspurs } \\
\hline D. nuttallianum & $20-60$ & $>1200$ & $\begin{array}{l}\text { mountain brush, sagebrush, aspen, } \\
\text { conifer, mountain and foothill } \\
\text { meadows }\end{array}$ & low to severe & $2-4$ \\
\hline D. bicolor & $20-40$ & $>800$ & mountain brush, sagebrush, & low to severe & - \\
\hline D. andersonii & $10-60$ & $>1200$ & $\begin{array}{l}\text { desert shrub, mountain brush, } \\
\text { sagebrush, pinion-juniper }\end{array}$ & low to moderate & $1-4$ \\
\hline
\end{tabular}

${ }^{1}$ The risk of losing cattle to these species is a subjective evaluation based on plant toxicity, numbers of grazing cattle threatened during the growing season, and the geographical distribution of the larkspur species. D. glaucescens is relatively more toxic late in the growing season compared to mature plants of the other species.

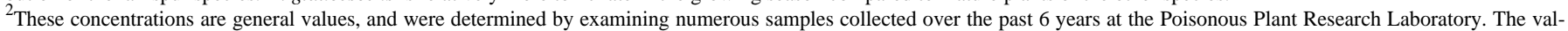
ues for low and plains larkspurs should be considered preliminary because they are based on small sample sizes. Multi-site and year analysis for low and plains larkspurs is ongoing (Gardner, unpublished data). For further references see review by Pfister et al. (1999). For concentrations in Canadian low larkspur, see Majak (1993).

and simultaneously select green locoweed. Once horses begin to eat locoweed, consumption may continue until they become very intoxicated.

Woolly locoweed (Astragalus mollissimus Torr.)

Woolly locoweed is not very palatable to grazing cattle, and probably is not selected by livestock unless grazing pressure is excessive (Ralphs et al. 1993). Consumption of woolly locoweed appears to cease with the growth of warm-season grasses (Ralphs et al. 1993).

\section{Social facilitation}

When some animals begin to eat locoweed, these 'locoeaters' can influence other grazing animals, including nursing calves, to begin eating locoweed through social modeling (Ralphs et al. 1994a). In most situations, ranchers should remove animals that eat locoweed to eliminate social influences, and to prevent progressive intoxication. Some producers in New Mexico with locoweed-infested pastures have reduced their locoweed losses by systematically, over several years, removing any cow from their herds seen eating locoweed, before the animal either becomes intoxicated or influences her calf or companions to eat locoweed (D. Graham, personal communication).

\section{Aversive Conditioning}

Grazing animals may be conditioned so that they will avoid toxic plants, including locoweed, in future encounters (Ralphs et al. 1997a). In this procedure, animals are given a taste of the plant in a corral, then dosed via stomach pump with a solution of lithium chloride $(\mathrm{LiCl})$ at $200 \mathrm{mg} / \mathrm{kg}$ body weight. The LiCl-induced illness is associated with the taste of the toxic plant, and animals avoid eating the target species (Ralphs 1992). Averted animals must not be allowed to graze with non-averted companions, as social facilitation can quickly extinguish the aversion (Ralphs 1997).

\section{Cyclic or "on-off” grazing}

Livestock can be poisoned by low level locoweed doses given for as little as 4 weeks (Pfister et al. 1996b). Nonetheless, considering both swainsonine's rapid clearance and dose-response threshold, it may be possible to expose animals briefly to locoweed with a low-risk of intoxication, if they are then allowed to recover on locoweed-free ranges. Recent work with sheep (Stegelmeier unpublished data) shows that animals repeatedly given locoweed for 10 days with a 14-day recovery period had no detectable permanent damage. On-off grazing schemes may work, but must be approached with caution as they have not been tested under field situations.

\section{Herbicidal control}

Producers should, if possible, provide a locoweed-free pasture for spring or fall grazing when animals are most likely to eat locoweed. Herbicidal control of locoweed (Ralphs and Ueckert 1988, McDaniel 1999) in some pastures can provide a relatively "loco-free" pasture for critical times. Herbicidal treatment for this specific purpose is often economical, even though general spraying to eliminate locoweed on a ranch-wide basis is usually not economical (Torell et al. 1999a).

\section{Diterpenoid alkaloids}

\section{Major Plant Species}

Toxic $\mathrm{C}_{19}$ and $\mathrm{C}_{20}$ norditerpenoid alkaloids occur primarily in 2 genera from Ranunculaceae: larkspurs (Delphinium spp.) and monkshood (Aconitum spp.). There are over 50 species each of Delphinium and Aconitum, but only a few are known to cause livestock poisoning. Monkshoods are highly toxic plants, but we believe that most reports of livestock losses to monkshood are attributable to larkspur (Knight and Pfister 1997). The 2 plants grow together in wet mountain habitats and are easily confused; furthermore, monkshood is not usually grazed by cattle. Larkspurs are divided into 3 general categories based primarily on mature plant height and distribution: low, tall, and plains (Table 4). Most research has focused on tall larkspurs (Pfister et al. 1999). Livestock losses in the western United States to all types of larkspurs probably exceed \$10 million dollars annually. 


\section{Toxic Alkaloids and Occurrence}

Larkspurs contain many (> 18) norditerpenoid alkaloids of which the most toxic are methyllycaconitine (MLA), 14deacetylnudicauline (DAN), and nudicauline (NUD; Manners et al. 1993, 1995). Both MLA and DAN occur to some extent in all classes of larkspurs, whereas NUD has not been found in tall larkspurs. A fourth alkaloid, deltaline, is relatively low in toxicity, but is the dominant alkaloid in most tall larkspurs, comprising $\geq$ $40 \%$ of the alkaloid composition, while MLA and DAN together comprise another 20 to $50 \%$ of the alkaloid mix in tall larkspurs. The MLA is the dominant alkaloid in low larkspurs (Majak et al. 1987, Majak and Engelsjord 1988, Bai et al. 1994).

The concentration of MLA and DAN is highest in immature larkspurs (Pfister et al. 1994a, Ralphs et al. 1997b). In tall larkspurs, MLA concentrations may exceed $20 \mathrm{mg} / \mathrm{g}$. In a Canadian study, Majak (1993) reported high concentrations of MLA (up to $8.7 \mathrm{mg} / \mathrm{g}$ ) in vegetative low larkspurs, and $2 \mathrm{mg} / \mathrm{g}$ in flowering plants. Before shattering, tall larkspur pods are relatively high in toxicity (MLA + DAN = 7 to $12 \mathrm{mg} / \mathrm{g}$ ). Toxicity declines rapidly in tall larkspurs once pods begin to shatter (Gardner and Pfister 2000), whereas concentrations are relatively stable in low larkspurs after the vegetative stage (Majak 1993, Gardner, unpublished data).

\section{Mechanism of intoxication}

The primary result of larkspur toxicosis in livestock is neuromuscular paralysis, as nicotinic acetylcholine (nAch) receptors in the muscle and brain are blocked by MLA and related alkaloids (Aiyar et al. 1979,
Dobelis et al. 1999). Animals usually die from respiratory failure (i.e., asphyxiation) when the muscles of the diaphragm are paralyzed or the CNS respiratory center is depressed. Larkspur alkaloid binding to nAch receptors appears to be correlated to toxicity in various tissues (Kukel and Jennings 1994), and may explain sheep tolerance to larkspur if larkspur toxins bind less avidly to nAch receptors in sheep (Stegelmeier et al. 1998b).

Toxicity, but not lethality of MLA + DAN has been established for cattle by oral doses of dried tall larkspur (Pfister et al. 1994b, 1997a). Cattle typically show clinical signs when given an MLA + DAN dose of about $20 \mathrm{mg} / \mathrm{kg}$ body weight (Pfister and Cheney 1998). A $450 \mathrm{~kg}$ cow may show clinical signs after rapidly eating $1.8 \mathrm{~kg}$ of tall larkspur $(\approx 7.2 \mathrm{~kg}$ wet weight). Assuming the plant material used in Olsen's (1978) LD 50 study (vegetative and early flowering tall larkspur) contained $12 \mathrm{mg} / \mathrm{g}$ of toxic alkaloid, the $\mathrm{LD}_{50}$ of MLA + DAN in cattle would be about $30 \mathrm{mg} / \mathrm{kg}$. Early studies by Marsh et al. (1916) suggest that the lethal dose is lower when tall larkspur is given repeatedly over 3 to 4 days.

\section{Clinical Signs}

Clinical signs of intoxication include muscular weakness and trembling, straddled stance, periodic collapse into sternal recumbency, respiratory difficulty, and finally death while in lateral recumbency. Moderately-intoxicated animals will periodically collapse while moving, and be in sternal recumbency for 10 to $30 \mathrm{~min}$; when the temporary paralysis subsides, affected animals may show muscular trembling, but will be able to walk and graze. Severely-intoxicated animals will be laterally-recumbent, and will be unable to do more than thrash about. Marsh et al. (1916) reported that bloat seldom occurs in intoxicated animals, but our observations suggest that bloat can be a significant component of larkspur fatalities. Bloating may occur as a result of paralysis of the rumen eructation (belching) mechanism. Cattle may die from bloat alone or asphyxiation from aspirated rumen contents while recumbent from larkspur paralysis. Some success of early remedies for larkspur poisoning (e.g., bacon fat and turpentine given orally, Glover 1906) may have been due to bloat reduction.

\section{Diagnosis and Treatment}

Diagnosis of larkspur poisoning is usually by association, as dead or sick animals are found near larkspur plants. Because larkspur poisoning causes no tissue lesions, pathological examination can only rule out other possible causes of death. Currently, no field test exists to determine if animals have been poisoned by larkspur. Blood or rumen fluid may contain larkspur alkaloids (Holstege et al. 1996); even so, cattle can eat substantial quantities of larkspur without ill effect, and the presence of alkaloids in body fluids only suggests larkspur intoxication.

A variety of remedies have been applied by ranchers (e.g., bleeding by cutting the tail), but most are without scientific rationale. Treated animals probably survive because they did not eat a lethal dose of larkspur and did not bloat. Drugs that increase acetylcholine concentration at the neuromuscular junction have potential for

Table 5. Relative pyrrolizidine alkaloid (PA) concentration and toxicity of various PA-containing plant species on western U.S. rangelands.

\begin{tabular}{|c|c|c|c|c|}
\hline Scientific name & Common name & Distribution & Concentration $^{1}$ & Lethal Dose ${ }^{2}$ \\
\hline & & & ---mg/g--- & ---mg/g---. \\
\hline $\begin{array}{l}\text { Cynoglossum } \\
\text { officinale }\end{array}$ & houndstongue & widespread weed in North America & 0.5 to $21^{3}$ & 5 to $60^{4}$ \\
\hline $\begin{array}{l}\text { Senecio } \\
\quad \text { longilobus }\end{array}$ & threadleaf groundsel & $\begin{array}{l}\text { midwest south into Texas and west into } \\
\text { New Mexico and Arizona }\end{array}$ & 1 to $87^{5}$ & 10 to $13^{6}$ \\
\hline riddellii & Riddell's groundsel & midwest south into west Texas and New Mexico & 2 to $180^{5}$ & 15 to $45^{7}$ \\
\hline jacobaea & tansy ragwort & weed in northwestern U.S. & 0.2 to $9^{5}$ & 2 to $3^{8}$ \\
\hline vulgaris & common groundsel & weed in western U.S. & 2 to $3^{5}$ & Not available \\
\hline
\end{tabular}

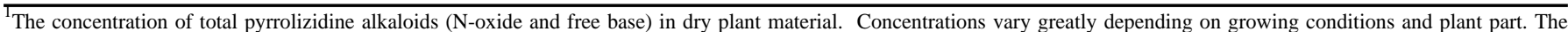
high value for $S$. riddellii $(180 \mathrm{mg} / \mathrm{g})$ is the highest recorded concentration of any type of alkaloid in any plant yet recorded (Molyneux and Johnson 1984).

${ }^{2}$ Lethal dose may be acute (short-term) or chronic (long-term) depending on dose, because toxicity from pyrrolizidine alkaloids may be delayed by weeks or months from the time animals ingest the plant.

${ }^{3}$ Pfister et al. 1992; Van Damm et al. 1994

${ }_{5}^{4}$ Baker et al. 1991; Stegelmeier et al. 1996

5 Johnson et al. 1985a; Molyneux and Johnson 1984

${ }^{6}$ Johnson and Molyneux 1984

${ }^{7}$ Johnson et al. 1985b; Molyneux et al. 1991

${ }^{8}$ Johnson and Smart 1983 
reversing larkspur toxicity. The cholinergic drug, physostigmine ( $0.08 \mathrm{mg} / \mathrm{kg}$ i.v.), has been successfully used under field and pen conditions to reverse clinical larkspur intoxication (Nation et al. 1982, Pfister et al. 1994c). Our current recommendation is that ranchers not attempt to move partially-paralyzed or recumbent animals, as stress is detrimental. If intoxicated animals bloat, passing a stomach tube or puncturing the rumen with a knife or trocar will relieve gas pressure.

\section{Impacts on Animal Nutrition and Behavior}

Larkspur poisoning is acute, rather than chronic, thus, animals that survive show essentially no long-term detrimental effects. Ingestion of larkspur at sub-acute doses has no negative impact on ruminal fermentation or digestive function (Pfister et al. 1989). Larkspur poisoning probably has no long-term effect on diet selection or grazing behavior, although previously-poisoned animals eat less larkspur and other forage for a few days after a toxic episode (Pfister et al. 1997a, Pfister and Cheney 1998). Eventually, larkspur consumption returns to previous levels, and animals may be intoxicated again.

\section{Grazing Management}

Tall larkspur (D. barbeyi Huth and $D$. occidentale (Wats.) Wats.)

Cattle eat little or no tall larkspur before the plant has elongated flowering racemes (Pfister et al. 1988a, 1997b). Cattle generally begin consuming tall larkspur after flowering racemes are elongated, and consumption increases as larkspur matures. Consumption usually peaks during the pod stage of growth in late summer, when catthe may eat large quantities (25 to $60 \%$ of diet, Pfister et al. 1988b).

The period of greatest risk on tall larkspur ranges extends from the flower stage into the pod stage. Many ranchers typically defer grazing on tall larkspur-infested ranges until the flower stage to avoid death losses. This approach wastes much valuable forage, and often places cattle into larkspur-infested pastures when risk of losses is high. An additional 4 to 6 weeks of grazing may be obtained by grazing these ranges early, before larkspur elongates flowering racemes (Pfister et al. $1997 \mathrm{~b}$ ). The risk of losing cattle is low when grazing before flowering even though larkspur is very toxic, because larkspur consumption is very low. Once pods are mature and begin to shatter, larkspur ranges can usually be grazed with impunity because pod toxicity declines rapidly, and leaf toxicity is low (Gardner and Pfister 2000).

Low larkspur (D. nuttallianum Pritz.) and Plains larkspur (D. geyeri Greene)

Consumption of low larkspur by cattle appears to increase once low larkspur has flowered, and higher grazing pressure will increase amounts of low larkspur eaten (Pfister and Gardner 1999). Spring grazing of low larkspur-infested ranges can be problematic, as there may not be sufficient forage growth to graze these ranges before larkspur flowers, but risk appears to increase once flowering occurs. Fortunately, in most years low larkspurs are short-lived, so producers must avoid heavily infested areas for about 4 weeks during peak toxicity. Four years of grazing studies on plains larkspur-infested ranges have shown few distinct patterns of consumption by lactating cows (Pfister, unpublished data).

\section{Other Management Options}

\section{Aversive Conditioning}

Cattle can be trained to avoid eating tall larkspur through aversive conditioning (Ralphs 1997), as previously noted with locoweed. Social facilitation, whereby one animal influences another to eat a particular plant, will quickly extinguish the aversion, thus, averted cattle must be grazed separately from non-averted cattle (Lane et al. 1990, Ralphs 1997). Animals experienced in eating larkspur may also be successfully averted, although the aversion is initially more difficult to induce and may be more fragile and less persistent than for naive animals (Ralphs 1997).

\section{Grazing Sheep Before Cattle}

Marsh et al. (1916) recommended that ranchers graze sheep before cattle to take advantage of the low toxicity to sheep, and Aldous (1917) noted that sheep grazing on immature $D$. occidentale in Nevada had reduced the poisoning risk to cattle. On tall larkspur-infested ranges where larkspur grows as discrete patches, sheep can be herded into or bedded on the patches to reduce larkspur availability or acceptability to cattle (Ralphs et al. 1991a, Ralphs and Olsen 1992). In those areas where larkspur is uniformly spaced over a pasture, sheep must eat immature larkspur and leave sufficient feed for cattle. This can be problematic, because early growth tall larkspur may not be palatable to sheep (Ralphs et al. 1991a). Sheep grazing has successfully reduced cattle losses on ranges with $D$. glaucescens in southwestern Montana ( $\mathrm{J}$. Helle, personal communication).

\section{Herbicidal Control}

Larkspur losses can be economically reduced if dense larkspur populations are controlled by herbicides. Picloram, metsulfuron, and glyphosate have proven to be effective in killing tall larkspurs when applied at specific growth stages (Mickelsen et al. 1990, Ralphs et al. 1991c, 1992). These herbicides do not reduce toxic alkaloid concentrations in treated larkspur plants, and metsulfuron may increase toxicity (Ralphs et al. 1998). Therefore, sprayed areas should not be grazed until larkspur has withered and decomposed.

\section{Pyrrolizidine Alkaloids}

\section{Major Plant Species}

Pyrrolizidine alkaloids (PAs) occur on western U.S. rangelands primarily in Senecio spp. (Asteraceae), and in Cynoglossum officinale L., (houndstongue, Boraginaceae). In the southeastern U.S., Crotalaria spp. (Fabaceae) also contain pyrrolizidine alkaloids. Worldwide, PAs are probably the most economically-important plant toxins impacting human health, as PAs contaminate grain for poultry, ruminant, and nonruminant livestock, and human consumption, as well as herbal teas (Huxtable 1989). About $3 \%$ of the flowering plants in the world (> 6000 species) contain PAs (Smith and Culvenor 1981), and there are currently nearly 300 individual known PAs (Roitman and Panter 1995). The alkaloid concentrations in range plants and subsequent toxicity vary widely (Table 5).

\section{Mechanism of intoxication}

The PAs occur in either the free-base or $\mathrm{N}$-oxide form in plants, but neither of these forms is toxic to animals per se (Winter and Segall 1989). The toxicity of PAs is due to the formation of toxic metabolites in the liver termed pyrroles. Pyrroles are formed as a detoxification intermediate through the action of liver enzyme systems, primarily mixed function oxidases (MFOs), but the exact mechanism is not clear (Winter and Segall 1989). Pyrroles form adducts within the liver with hepatic proteins and nucleic acids, and damage liver cells, causing enlarged hepatocytes, abnormal bile secretion, and fibrosis (Stegelmeier et al. 1996). A dysfunctional liver leads to other syndromes such as chronic wasting disease and photosensitization. The PAs can also cause lesions in the lungs and brain. 


\section{Clinical Signs and Diagnosis}

Poisoning from PAs may be either acute (high-dose and short-term) or chronic (lower-dose and long-term). Acute intoxication is less common, as most animals poisoned by PAs develop clinical signs slowly over many weeks or months (Cheeke 1989). Acute intoxication can kill animals within 1 day if sufficient plant material is ingested (Baker et al. 1991). Chronic intoxication usually results from ingestion of the PA-containing plant for several weeks (Baker et al. 1991, Stegelmeier et al. 1996). Typical clinical signs include depression and lethargy, anorexia, and ascites (fluid accumulation in abdomen). None of these signs are specific for PA-induced toxicity, thus, the diagnosis is usually made from a liver biopsy and associated histopathology. Enlarged liver cells were the dominant lesion seen in horses 6 months after they were dosed with a low dose of alkaloids. Serum chemistry changes may be dramatic, as many liver enzymes are altered, but these changes are also not specific for PApoisoning. Wasting disease (i.e., severe emaciation) as a result of liver damage is commonly noted, as is "hard, yellow liver" disease; all these conditions may be related to PA-induced damage to the liver, but can be caused by other toxic plants and diseases (Stegelmeier et al. 1996).

Younger animals are more susceptible to PA-induced toxicosis because the higher metabolic activity of growing liver tissue encourages pyrrole formation and results in more extensive liver damage (Cheeke 1989). The PAs are transferred in milk to nursing young, and there is a danger of human consumption via milk (Molyneux and James 1990). There are marked species differences in tolerance for PAs, as goats and sheep are relatively more resistant to PA-poisoning than cattle and horses (Cheeke and Huan 1995). Detoxification of PAs occurs to a limited extent in the rumen (Wachenheim et al. 1992), but the liver appears to be the major site of detoxification (Cheeke 1994).

\section{Impacts on Animal Nutrition and Behavior}

Poisoning by PAs clearly has a great impact on the nutrition of grazing and penfed animals. Animals with compromised liver function will generally show slow weight loss over a long period of time (perhaps years). Further, PA-intoxication may interfere with mineral and vitamin nutrition to further degrade animal performance (Cheeke 1989).

Intoxication by PAs can affect animal behavior directly. For example, horses may show typical "head pressing" behavior as a result of ammonia toxicity from liver damage (Cheeke 1989). Intoxicated animals may become intractable and difficult to handle as the disease progresses; in the final stages of poisoning animals may stagger greatly. Liver damage can lead to secondary photosensitization, and as affected animals are sensitive to sunlight, they become solitary and spend excessive amounts of time seeking shade instead of grazing. Severe sunburn may occur especially on exposed areas such as the nose, vulva, udder, etc. Photosensitized, lactating cows will often develop very inflamed and sensitive udders, especially light-pigmented animals, and will prematurely wean their nursing young.

\section{Management and Control \\ Senecio species}

Managing rangelands so that plant communities are in good condition and adequate forage is available is crucial to reducing losses to Senecio spp. (Merrill and Schuster 1978). Generally, senecios are not very palatable, and are avoided by grazing livestock if other forage is available. Drought stress and overgrazing can increase populations of threadlleaf groundsel, as the plant is an aggressive invader (Sharrow et al. 1988). Drought is an especially dangerous time because other forage may be lacking and the toxic alkaloid concentration in senecio plants increases during drought (Molyneux and Johnson 1984), so grazing animals may ingest higher quantities of more toxic forage. Senecio species are also most toxic when plants are reproducing, thus avoiding pastures when these plants are in bud, flower, or seed is prudent. Proper grazing management must consider stocking rates, as improper stocking may increase the amount of toxic plant consumed when alternative forages become limited. Excessive stocking may lead to degradation of the desirable plant community allowing Senecio species to increase. Herbicidal control may alleviate some problems if incorporated into an overall management program (Sharrow et al. 1988).

\section{Houndstongue (Cynoglossum officinale)}

Houndstongue is not only a toxic plant, but also a noxious weed that is increasing in North America. The plant spreads from bur-like seeds that cling to animals and humans alike, and invades disturbed areas. Houndstongue is generally unpalatable when growing on rangelands, but we have observed lactating cows eat green hounds- tongue when other forage was adequate (Pfister unpublished observations). When houndstongue contaminates hay, it is readily eaten by cattle and horses, and is quite toxic (Baker et al. 1989).

\section{Quinolizidine Alkaloids}

\section{Major Plant Species}

The most problematic plant genera with quinolizidine alkaloids is Lupinus (Fabaceae). Although lupine is cultivated in some parts of the world as forage or grain (so-called sweet lupine), in the western U.S. many wild lupine species are toxic to livestock because of high alkaloid concentrations (Keeler 1989). Wink et al. (1995) recently reported on the alkaloid concentration of 36 lupine species from North America; most contain quinolizidine alkaloids, but a few also contain piperidine alkaloids or both types of alkaloids.

\section{Mechanisms of Intoxication}

Quinolizidine alkaloids are both toxic and teratogenic (i.e., causing birth defects) to livestock (Panter and James 1995). Lupines cause respiratory failure in sheep (Kingsbury 1964), but the mechanism is unknown. Lupine alkaloids bind differentially to both nicotinic and muscarinic Ach receptors (Schmeller et al. 1994), and affect $\mathrm{Na}^{+}$and $\mathrm{K}^{+}$ion channels (Wink et al. 1995), but a specific relationship to toxicity has not been developed. Birth defects are apparently caused by the effects of 2 different, but related, alkaloids, anagyrine (a quinolizidine alkaloid, Table 6) and ammodendrine (a piperidine alkaloid; Panter et al. 1992). For unknown reasons, cattle are uniquely sensitive to the effects of anagyrine, and ingestion of alkaloid-rich lupine causes the condition "crooked calf disease" in bovine offspring (Table 6, Keeler 1989, Panter et al. 1994). Crooked calf disease has been associated with Lupinus laxiflorus Douglas ex Lindl., L. caudatus Kellogg, and L. sericea Pursh (Panter et al. 1992). Crooked calf disease is caused by reductions in fetal movement during a susceptible period in gestation (Panter et al. 1988a). This reduction in fetal movement at the critical time is likely to interfer with bone, muscle and ligament development, resulting in mild to lethal skeletal malformations and cleft palate in calves (Panter et al. 1990, 1988a). Even though many calves are born alive, most of these deformities make them virtually worthless, and most deformed calves are destroyed shortly after birth. 
Table 6. Potentially teratogenic Lupinus species on western U.S. rangelands ${ }^{1}$. Ingestion by pregnant cattle of Lupinus species with teratogenic alkaloids (quinolizidine or piperidine) from gestation day 40-100 may cause severe deformities in calves (i.e., crooked calf disease).

\begin{tabular}{|c|c|}
\hline Scientific name & Common name \\
\hline 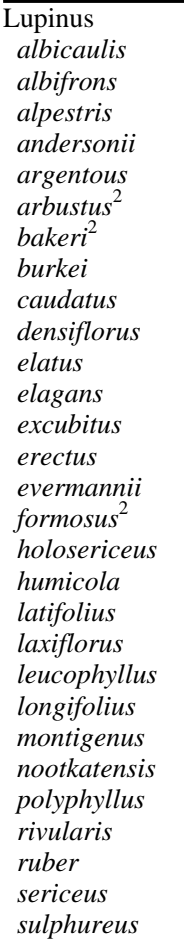 & $\begin{array}{l}\text { tall silvery lupine } \\
\text { Everman's lupine } \\
\text { Lunara lupine } \\
\text { lowland lupine } \\
\text { broadleaf lupine } \\
\text { looseflower lupine } \\
\text { velvet lupine } \\
\text { Mt. Rose lupine } \\
\text { Nootka lupine (Alaska) } \\
\text { Washington lupine } \\
\text { stream lupine } \\
\text { red lupine } \\
\text { silky lupine } \\
\text { yellow lupine }\end{array}$ \\
\hline
\end{tabular}

Adapted from Davis (1982), Davis and Stout (1986) and Wink et al. (1995). Species were listed if they contain any of the quinolizidine alkaloid, anagyrine.

${ }^{2}$ These species contain piperidine alkaloids (e.g., ammondendrine) that are also teratogenic when eaten by cattle (Panter et al. 1998b).

\section{Clinical signs}

Lupine toxicity is seen clinically as a neurologic disease that progresses from depression and lethargy to muscular weakness, collapse, respiratory failure and death (Panter et al. 1999). Animals that survive for 1 or 2 days may recover completely (Panter et al. 1999), or they may succumb several days later (Kingsbury 1964). Pregnant cows that eat small amounts of lupine may not show clinical signs of intoxication, but give birth to deformed offspring (e.g., cleft palate, Panter et al. 1994). While sheep, goats, and cattle may show signs of acute lupine toxicity such as depression and death, the anygyrine-containing lupines cause birth defects in cattle only (Panter et al. 1998b).

\section{Impacts on Animal Nutrition}

Many lupines are not toxic to livestock, and plant breeders have conducted extensive breeding programs to enhance lupines nutritional properties and to reduce their alkaloid content for both livestock and human consumption (Aniszewski 1993). Lupines, being legumes, may contain > $20 \%$ crude protein (Panter et al. 1999). So-called "sweet" lupines are relatively low in alkaloid concentrations, and are an excellent source of protein for livestock (Stanford et al. 1996). Range-grown lupines, particularly the seed pods, are a good source of nutrition if they are low enough in alkaloids that toxicity problems do not develop (Panter et al. 1999).

\section{Management and Control}

Losses of livestock from lupine poisoning can largely be prevented by understanding 2 interrelated aspects. First, the highest concentrations of toxic alkaloids tend to occur in immature lupine plants and seed pods. Anagyrine concentrations are highest (> $5 \mathrm{mg} / \mathrm{g}$ ) in early growth, and decline to less than $0.5 \mathrm{mg} / \mathrm{g}$ after seed shatter, except that concentrations increase when lupine seeds ripen (Keeler 1976). Second, pregnant cattle are susceptible to the teratogenic effects of alkaloids during a window from days 40 to 70 of gestation, occasionally extending to 100 days (Panter et al. 1997). Birth defects in cattle can be prevented by using breeding or grazing programs that avoid placing pregnant cattle in lupine-dominated pastures in the first trimester of gestation (Keeler et al. 1977, Panter et al. 1992, 1999). Alternatively, risk can be reduced by allowing only short-term access to lupines by pregnant cattle in some form of rotational grazing scheme (Panter et al. 1999). Herbicidal control of lupines is feasible (Ralphs et al. 1991d), but chemical control is usually more expensive than altering a grazing management program.

Acute toxicity problems are less common now, but large sheep losses occurred frequently 100 years ago (Chesnut and Wilcox 1901). Deaths losses usually occur when livestock, usually sheep, ingest a large amount of seed pods in a short period of time (James et al. 1968). This can occur from contaminated hay or from hungry animals gaining access to lupine-dominated forage, and can be prevented by using lupine-free hay and avoiding lupinedominated ranges when other forage is scarce. During some years, lupine populations will temporarily expand on rangelands not normally problematic. Livestock producers need to be aware of lupine populations and be sufficiently alert to alter grazing or breeding programs when these eruptions occur. Lupine populations increased dramatically during 1997 in
Washington, Oregon, Idaho, and Montana, causing severe losses. For example, producers in Adams County, Washington lost over $30 \%$ of their calves (> 4000 calves) from lupine-caused birth defects (Panter et al. 1999).

\section{Piperidine Alkaloids}

\section{Major Plant Species}

Piperidine alkaloids are broadly distributed in nature, but only a few range plants have sufficient amounts to cause toxicity problems for domestic livestock. Several Lupinus species (Fabaceae) contain piperidine alkaloids (Table 6), in addition to quinolizidine alkaloids (Roitman and Panter 1995). The suspected toxic piperidine alkaloids in Lupinus are ammondendrine and Nmethyl hystrine (Panter and James 1995). Recently, 8 yearling steers died after eating Lupinus argenteus Pursh containing high levels of ammondendrine and N-methyl ammodendrine (Panter, personal communication). These cattle began grazing $L$. argenteus after grasses were depleted.

The most prominent species containing piperidine alkaloids is poison hemlock (Conium maculatum L., Apiaceae). Only 1 species of Conium grows in North America, and should not be confused with water hemlock (Cicuta maculata L.). Poison hemlock grows in disturbed areas, waste land, and along waterways, invading perennial hayfields and pastures. The first alkaloid ever characterized (coniine) was isolated from poison hemlock in 1827 (Panter and Keeler 1989). In addition to coniine, poison hemlock contains 4 other alkaloids, of which the most toxic alkaloid is $\Upsilon$-coniceine, the biogenic precursor for the other Conium alkaloids (Panter and Keeler 1989). The $\Upsilon$-coniceine is about 8 times more toxic than coniine (Bowman and Sanghvi 1963, Panter et al. 1998a), and this difference has important management implications.

\section{Alkaloid Occurrence}

The alkaloid concentration and distribution of alkaloids in poison hemlock are affected by many factors, including environmental changes and plant maturity (Cromwell 1956, Leete and Olson 1972). Drought stress increases total alkaloid concentrations (Fairbairn and Challen 1959). Immature poison hemlock often has a high concentration of $\Upsilon$-coniceine, which may then be converted predominately into coniine during active growth. During flowering, concentrations of $\Upsilon$-coniceine also shift to coniine. Thus, coniine is 
the major alkaloid in mature plants and seed, whereas $\Upsilon$-coniceine dominates the alkaloid mix in early growth and fall regrowth. Leaves from young or regrowing plants contain 3 to $6 \mathrm{mg} / \mathrm{g}$ of toxic alkaloids, whereas immature and mature fruit may contain $>10 \mathrm{mg} / \mathrm{g}$ (Cromwell 1956).

\section{Mechanism of Intoxication}

Poison hemlock alkaloids act on both smooth and striated muscle; the effect on skeletal muscle is a curare-like neuromuscular blockage, similar to larkspurs. Unlike larkspur alkaloids, blockage occurs only after initial muscular stimulation (Bowman and Sanghvi 1963). When the dose is sufficient, the blockage causes muscular paralysis, resulting in depressed respiration. The specific site of blockage at the neuromuscular junction is not known, nor is the exact mechanism (Panter and Keeler 1989). Poison hemlock alkaloids are also potent teratogens, and ingestion during pregnancy induces skeletal malformations that are virtually indistinguishable from those caused by lupines (Panter et al. 1988b). The mechanism of fetotoxicity is thought to be the same, namely reductions in fetal movement during critical phases of gestation (Panter et al. 1988a).

\section{Clinical Signs and Diagnosis}

Poison hemlock causes initial CNS stimulation with frequent urination and defecation, dilated pupils, increased heart rate, muscular weakness and trembling and ataxia. This initial stage is followed by depression with further muscular weakness, collapse, and death due to respiratory paralysis (Panter et al. 1988b). Although animals exhibit tremors, muscular weakness and collapse, they do not have true seizures and may recover quickly if a sublethal dose was eaten. Although poison hemlock is fetotoxic to pregnant animals as are lupines, Conium is more universally teratogenic, affecting cattle, sheep, goats, and pigs (Panter and Keeler 1989). Most pregnant animals that later develop terata after ingesting poison hemlock also show initial signs of acute toxicity, and many are fatally intoxicated, unlike the teratogenesis from lupine alkaloids. The severity of birth defects varies according to the dose and the animal species. Sheep are less sensitive than are cattle, goats, and pigs (Panter et al. 1988b). Similar birth defects can be caused by genetic, traumatic, or other environmental toxins and the clinical signs and lesions are nonspecific. Because there are no definitive pathological lesions, the diagnosis of poison hemlock toxicity is made from a knowledge of exposure to the plant, and from clinical signs. Additionally, many reports suggest that affected animals have a "mousy" odor on their breath or urine. Alkaloid screening can detect the presence of poison hemlock alkaloids in body fluids, providing confirmation that animals were ingesting the plant (Galey et al. 1992).

\section{Management and Control}

The most critical time of the year to avoid poison hemlock is spring because the plant often appears before other forage has emerged. Green seed pods may be eaten in mid-to-late summer (Panter and Keeler 1989). Furthermore, poison hemlock may regrow in fall after seed shatter. Ingestion during fall may coincide with fetotoxicity in pregnant cattle, if they are in the first trimester (days 30-75, Panter et al. 1988b). If poison hemlock has invaded hay fields, the contaminated hay can poison livestock. Even though toxicity decreases upon drying, sufficient toxin may be retained to poison livestock (Galey et al. 1992). Cattle appear to be particularly susceptible because of their acceptance of the plant and their sensitivity to the teratogenic alkaloids. Poison hemlock can be easily controlled with phenoxy herbicides (Panter et al. 1988b).

\section{Impacts on Grazing Behavior}

Poison hemlock is reported to be habituating or even addictive (Kingsbury 1964, Panter and Keeler 1989). Goats (Copithorne 1937), cows (Penny 1953), and pigs (Panter et al. 1985) readily eat fresh hemlock, even when intoxicated. Panter (1983) reported that intoxicated pigs "relished" the plant, and seemingly developed a craving for poison hemlock.

\section{Related Pyridine Alkaloids}

Tree and wild tobacco (Nicotiana spp., Solanaceae) are the primary toxic plants in the U.S. that contain pyridine alkaloids, closely related to piperidine alkaloids (Roitman and Panter 1995). Several species of Nicotiana poison livestock in the western U.S. (Kingsbury 1964), including N. tabacum (Burley tobacco), N. glauca (tree tobacco), N. trigonophylla (wild tobacco) and N. attenuata (wild tobacco). Tree and wild tobacco plants are generally not palatable to livestock grazing on rangelands (Panter et al. 1992). These plants contain nicotine, a wellknown toxin, and more importantly, the teratogenic piperidine alkaloid, anabasine
(Keeler 1979). Anabasine causes fetal malformations virtually indistinguishable from those caused by Lupinus and Conium (Panter and James 1995).

\section{Steroidal (Veratrum-type) Alkaloids}

\section{Major Plant Species}

The steroidal veratrum-type alkaloids are found primarily in Veratrum species (false hellebore) and Zigadenus species (death camas, Liliaceae). Western falsehellebore (Veratrum californicum Durand) is the dominant species in the western U.S., and occurs in moist mountain meadows, and along slopes and stream banks. Death camas grows on plains, prairies, and foothill ranges throughout the western U.S. There are several species of death camas, and all should be considered toxic even though toxicity can vary within and among species (Panter and James 1989).

\section{Alkaloids and Mechanism of Intoxication \\ Veratrum species}

False hellebore has long been recognized as a toxic plant for livestock (Hall and Yates 1915), although false-helleboreinduced fetotoxicity in sheep was not reported until 1962 (Binns et al. 1962). The primary teratogen is cyclopamine; the closely-related alkaloid veratramine is very toxic but does not produce abnormalities (Keeler 1983). Ingestion of false hellebore by pregnant sheep on gestation day 14 results in "monkey-faced" or cyclopian lambs with potentially severe craniofacial defects (Binns et al. 1962). The facial defects result from the toxic insult to the neural tube such that the embryonic forebrain fails to divide normally. Veratrum alkaloids have a structural resemblance to cholesterol. Recent work suggests that a disruption in cholesterol transport within cells prevents brain cells from recognizing signals to divide properly (Incardona et al. 1998). Other work suggests that cyclopamine may act by competitive binding at Ach receptors (Keeler 1988). Other defects and fetal death are possible at later stages of gestation up to 33 days (Keeler et al. 1986). Sheep are primarily affected because of their propensity to eat false hellebore but cattle and goats are also susceptible. A single dose of $1.5 \mathrm{~g}$ of purified alkaloid will cause deformities in sheep (Keeler 1983). 


\section{Death camas}

Zygadenine was the first steroidal alkaloid found in death camas, but the toxicity has been attributed to zygacine, an acetyl ester of zygadenine (Majak et al. 1992, Makeiff et al. 1997). Zygacine concentrations range from 2 to $4 \mathrm{mg} / \mathrm{g}$, and are highest in vegetative tissue and pods (Majak et al. 1992). Majak et al. (1992) also reported that 2 related forms of zygadenine were not detected in vegetative plants, but concentrations of these alkaloids increased dramatically in pods. The mechanism of action is not known. Zygadenine and numerous related alkaloids were found in death camas (Lang and Smith 1998) collected at the site where 23 cows died in Nebraska (Collett et al. 1996).

\section{Clinical Signs and Diagnosis Veratrum species}

Clinical signs of acute false hellebore poisoning, relatively rare in livestock, include salivation, recumbency, reduced heart rate, and dyspnea (Kingsbury 1964). The fetotoxic effects of false hellebore are not generally overt for the dam. If fetal deformities are severe, the hormonal signals inducing parturition are disrupted and the dead and deformed fetus will be carried well beyond term. These ewes will eventually show clinical signs from the extended gestation and usually die (James 1999).

\section{Death camas}

Death camas toxicity is characterized by excessive salivation, frothing around the mouth, nausea and sometimes vomition (Kingsbury 1964, Panter et al. 1987). If the dose is sufficient, muscular weakness is followed by ataxia, recumbency, and death. Affected animals have a rapid, weak heartbeat, and respiratory distress. Death is from heart failure (Panter et al. 1987). Diagnosis is made by recognizing the clinical signs of poisoning, association of affected animals with populations of grazed plants, and pathological examination of tissues from dead animals (Panter and James 1989).

\section{Management and Control Veratrum species}

Livestock management to avoid losses to false hellebore are relatively simple. First, since the window of fetotoxicity is relatively narrow (i.e., 14 to 33 days gestation), pregnant animals (particularly sheep) should not be allowed access to veratrum-infested pastures during this period. Cattle rarely eat the plant, there- fore no special management is needed. For sheep, false hellebore is quite palatable, and herders must keep bred sheep from ingesting false hellebore for about 1 month after the rams are removed (Panter et al. 1992). This is not difficult to accomplish because false hellebore is limited in distribution to moist mountain habitats and grows in easy to identify dense patches. Although effective herbicidal control is available (Williams and Cronin 1981), it may not be practical given the location of the major populations in National Forests and the ease with which the problem can be solved by grazing management.

\section{Death camas}

Death camas is one of the first plants to grow during spring, and animals may graze the plant if other forage is lacking. Generally, recognizing the presence of death camas and understanding the acutely toxic nature of the plant will aid in avoiding problems. Panter et al. (1987) identified 3 contributing circumstances that resulted in loss of over 250 sheep in one band. First, hungry ewes with lambs were driven through the death camas-infested pasture. Second, sheep were bedded near the death camas, so the plant was readily available for grazing. Third, the herder stressed the sheep by rapidly driving them from the area, thus increasing the death loss (Panter et al. 1987). Death camas can be controlled by phenoxy herbicides (Ralphs et al. 1991d).

\section{Conclusions}

Alkaloid-containing plants exact a heavy economic toll on livestock production in rangelands of western North America. Losses to these plants can be reduced or eliminated by recognizing the toxic plant responsible for specific losses, understanding when livestock graze the plant and how the toxin affects animals, altering management schemes or animal species to reduce the risk of losses, or using herbicidal control. Management of each toxic plant species is based on knowledge of the temporal and spatial dynamics of alkaloid concentration and consumption by livestock. Losses may be reduced by ensuring that livestock are not exposed or have reduced exposure either during periods of greatest risk (e.g., highest toxin concentrations), or when they are most likely to eat the plant in amounts sufficient to cause toxicity.

\section{Literature Cited}

Aiyar, V.N., Benn, M.H., Hanna, T., Jacyno, J., Roth, S.H., and Wilkens, J. 1979. The principal toxin of Delphinium brownii Rydb., and its mode of action. Experientia 35, 1367-1368

Aldous, A.E. 1917. Eradicating tall larkspur on cattle ranges in the National Forests. USDA Farmers Bull. 826.

Aniszewski, T. 1993. Nutritive quality of the alkaloid-poor Washington lupine (Lupinus polyphyllus Lindl var SF/TA) as a potential protein crop. J. Sci. Food Ag. 61:409-421.

Arnold, G.W. and J.L. Hill. 1972. Chemical factors affecting selection of food plants by ruminants, p. 71-101. In: J.B. Harborne (ed.), Phytochem. Ecol.. Academic Press, London.

Bai, Y., F. Sun, M. Benn, M., and W. Majak. 1994. Diterpenoid and norditerpenoid alkaloids from Delphinium nuttallianum. Phytochem. 37: 1717-1724.

Baker, D.C., J.A. Pfister, R.J. Molyneux, and P. Kechele. 1991. Cynoglossum officinale toxicity in calves. J. Comp. Path. 104: 403-410.

Baker, D.C., R.A. Smart, M.H. Ralphs, and R.J. Molyneux. 1989. Hound's-tongue (Cynoglossum officinale) poisoning in a calf. J. Am. Vet. Med. Assoc 194:929-930.

Bate-Smith, E.C. 1972. Attractants and repellants in higher animals. p. 45-56. In: J.B. Harborne (ed.), Phytochem. Ecol. Academic Press, London.

Binns, W., L.F. James, J.L. Schupe, and E.J. Thacker. 1962. Cyclopian-type malformation in lambs. Arch. Environ. Health 5:106-108

Bowman, W.C. and I.S. Sanghvi. 1963. Pharmacological actions of hemlock (Conium maculatum) alkaloids. J. Pharm. Pharmacol. 15:1-25.

Broquist, H.P. 1986. Livestock toxicosis, slobbers, locoism, and the indolizidine alkaloids. Nutr. Rev. 44:317-323.

Cheeke, P.R. 1989. Pyrrolizidine alkaloid toxicity and metabolism in laboratory animals and livestock. p. 1-22. In: P.R. Cheeke (ed.), Toxicants of Plant Origin. Vol. 1, Alkaloids. CRC Press, Boca Raton, Fla.

Cheeke, P.R. 1994. A review of the functional and evolutionary roles of the liver in the detoxification of poisonous plants, with special reference to pyrrolizidine alkaloids. Vet. Human Tox. 36:240-247.

Cheeke, P.R. and J. Huan. 1995. Metabolism and toxicity of pyrrolizidine alkaloids. p. 155-164 In: D.L. Gustine and H.E. Flores (eds.), Phytochemicals and Health. Amer. Soc. Plant Physiol. Ser., Vol. 15. Rockville, Maryland.

Chesnut, V.K. and E.V. Wilcox. 1901. The stock-poisoning plants of Montana. USDA Bull. 26.

Colegate, S.M. and P.R. Dorling. 1997. Bioactive indolizidine alkaloids. p. 1-18. In: J.P. F. D'Mello (ed.), Handbook of Plant and Fungal Toxicants. CRC Press, Boca Raton, Fla. 
Colegate, S.M., P.R. Dorling, and C.R. Huxtable. 1989. Structural elucidation of swainsonine: relationship of structure to activity. p. 91-99. In: L.F. James, A.D. Elbein, R.J. Molyneux, and C.D. Warren (eds.), Swainsonine and Related Glycosides Inhibitors. Iowa State Univ. Press, Ames, Ia.

Collett, S., D. Grotelueschen, R.A. Smith, and R. Wilson. 1996. Deaths of 23 adult cows attributed to intoxication by the alkaloids of Zygadenus venenosus (Meadow death camas). Agri-Prac. 17:5-9.

Copithorne, B. 1937. Suspected poisoning of goats by hemlock (Conium maculatum). Vet. Rec. 49:1018-1019.

Cromwell, B.T. 1956. The separation, micro-estimation and distribution of the alkaloids of hemlock (Conium maculatum). Biochem. J. 64:259-266.

Davis, A.M. 1982. The occurrence of anagyrine in a collection of western American lupines. J. Range Manage. 35:81-84.

Davis, A.M. and D.M. Stout. 1986. Anagyrine in western American lupines. J. Range Manage. 39:29-30.

Davis, D., T. Hernandez, M. Mitchell, P. Schwartz, B. Warnock, and A.D. Elbein. 1984. Isolation and characterization of swainsonine from Texas locoweed (Astragalus emoryanus). Plant Physiol. 76:972-975.

Dobelis, P., J.E. Madl, J.A. Pfister, G.D. Manners, and J.P. Walrond. 1999. Effects of Delphinium alkaloids on neuromuscular transmission. J. Pharm. Exp. Therap. 291:538-546.

Dorling, P.R., S.M. Colegate, and C.R. Huxtable. 1989. Swainsonine: a toxic indolizidine alkaloid. p. 237-250. In: P.R Cheeke (ed.), Toxicants of Plant Origin. Vol 1, Alkaloids. CRC Press, Boca Raton, Fla.

Elbein, A.D. 1989. The effect of plant indolizidine alkaloids and related compounds on glycoprotein processing. p. 155-187. In: L.F. James, A.D. Elbein, R.J. Molyneux, and C.D. Warren (eds.), Swainsonine and Related Glycosides Inhibitors. Iowa State Univ. Press, Ames, Ia.

Fairbairn, J.W., and S.B. Challen. 1959. The alkaloids of hemlock (Conium maculatum): distribution in relation to the development of the fruit. Biochem. J. 72:556-561.

Fox, W.E., K.W. Allred, and E.H. Roalson. 1998. A guide to the common locoweeds and milkvetches of New Mexico. N.M. Agr. Expt. Sta. Cir. 557.

Galey, F.D., D.M. Holstege, and E.G. Fisher. 1992. Toxicosis in dairy cattle exposed to poison hemlock (Conium maculatum) in hay: isolation of Conium alkaloids in plants, hay, and urine. J. Vet. Diagn. Invest. 4:60-64.

Garcia, J. and W.G. Hankins. 1975. The evolution of bitter and the acquisition of toxiphobia. p. 39-45. In: D.A. Denton and J.P. Coghlan (eds.), Olfaction and Taste, Vol. 5. Academic Press, New York, N.Y.

Gardner, D.R. and J.A. Pfister. 2000. Late season toxic alkaloid concentrations in tall larkspur (Delphinium spp.) J. Range Manage. 53:331-336.
Glendinning, J.I. 1994. Is the bitter rejection response always adaptive? Physiol. Behav. 56:1217-1227.

Glover, G.H. 1906. Larkspur and other poisonous plants. Colo. Ag. Expt. Sta. Bull. 113.

Hall, H.M. and H.S. Yates. 1915. Stock Poisoning Plants of California. Calif. Ag. Expt. Sta. Bull. 249.

Hazlett, D.L. and N.W. Sawyer. 1998. Distribution of alkaloid-rich plant species in shortgrass steppe vegetation. Cons. Biol. 12:1260-1268.

Hegnauer, R. 1963. The taxonomic significance of alkaloids. p.389-427. In: T. Swain (ed.), Chemical Plant Taxonomy, Academic Press, London.

Hegnauer, R. 1988. Biochemistry, distribution and taxonomic relevance of higher plant alkaloids. Phytochem. 27:2423-2427.

Holstege, D.M., F.D. Galey, B. Johnson, and J.N. Seiber. 1996. Determination of alkaloid exposure in a model ruminant (goat) using a multi-residue screening method. J. Agr. Food Chem. 44:2310-2315.

Huxtable, R.J. 1989. Human health implications of pyrrolizidine alkaloids and herbs containing them. p. 41-86. In: P.R. Cheeke (ed.), Toxicants of Plant Origin. Vol. 1, Alkaloids. CRC Press, Boca Raton, Fla.

Incardona, J.P., W. Gaffield, R.P. Kapur, and H. Roelink. 1998. The teratogenic veratrum alkaloid cyclopamine inhibits sonic hedgehog transduction. Develop. 125:3553-3562.

James, L.F. 1999. Teratological research at the USDA-ARS Poisonous Plant Laboratory. J. Nat. Toxins 8:63-80.

James, L.F. and W.J. Hartley. 1977. Effects of milk from animals fed locoweed on kittens, calves and lambs. J. Amer. Vet. Res. 38:1263-1265.

James, L.F. and K.R. Van Kampen. 1971. Acute and residual lesions of locoweed poisoning in cattle and horses. J. Amer. Vet. Med. Assoc. 158:614-618.

James, L.F., W. Binns, and J.L. Shupe. 1968. Blood changes in cattle and sheep fed lupine. Amer. J. Vet. Res. 29:557-560.

James, L.F., K.R. Van Kampen, and G. Staker. 1969. Locoweed (Astragalus lentiginosus) poisoning in cattle and horses. J. Amer. Vet. Med. Assoc. 155:525-530.

James, L.F., W.F. Hartley, K.R. Van Kampen, and D.B. Nielsen. 1983. Relationship between ingestion of the locoweed Oxytropis sericea and congestive right-sided heart failure in cattle. Amer. J. Vet. Res. 44:254-259.

Johnson, A.E. and R.J. Molyneux. 1984. Toxicity of threadleaf groundsel (Senecio douglasii var longilobus) to cattle. Amer. J. Vet. Res. 45:26-31.

Johnson, A.E. and R.A. Smart. 1983. Effects on cattle and their calves of tansy ragwort (Senecio jacobaea) fed in early gestation. Amer. J. Vet. Res. 44:1215-1219.

Johnson, A.E., R.J. Molyneux, and G.B. Merrill. 1985a. Chemistry of toxic range plants. Variation in pyrrolizidine alkaloid content of Senecio, Amsinckia, and Crotalaria species. J. Agr. Food Chem. 33:50-55.
Johnson, A.E., R.J. Molyneux, and L.D. Stuart. 1985b. Toxicity of Riddell's groundsel (Senecio riddellii) to cattle. Amer. J. Vet. Res. 46:577-582.

Keeler, R.F. 1976. Lupin alkaloids from teratogenic and nonteratogenic lupins: III. Identification of anagyrine as the probable teratogen by feeding trials. J. Tox. Environ. Health 1:887-898.

Keeler, R.F. 1979. Congenital defects in calves from maternal ingestion of Nicotiana glauca of high anabasine content. Clin. Toxicol. 15:417-420.

Keeler, R.F. 1983. Naturally occurring teratogens from plants. p. 161-199. In: R.F. Keeler and A. T. Tu (eds.), Handbook of Natural Toxins. Marcel Dekker, Inc., New York.

Keeler, R.F. 1988. Livestock models of human birth defects, reviewed in relation to poisonous plants. J. Anim. Sci. 66:2414-2427.

Keeler, R.F. 1989. Quinolizidine alkaloids in range and grain lupins. p. 133-167. In: P.R. Cheeke (ed.), Toxicants of Plant Origin. Vol. 1, Alkaloids. CRC Press, Boca Raton, Fla.

Keeler, R.F., L.D. Stuart, and S. Young. 1986. When ewes ingest poisonous plants: the teratogenic effects. Vet. Med. Food-Anim. Prac., May:449-454.

Keeler, R.F., L.F. James, J.L. Schupe, and K.R. Van Kampen. 1977. Lupine-induced crooked calf disease and a management method to reduce incidence. J. Range Manage. 30:97-102.

Kingsbury, J.M. 1964. Poisonous Plants of the United States and Canada. Prentice-Hall, Inc., Englewood Cliffs, N.J.

Knight, A.P. and J.A. Pfister. 1997. Larkspur poisoning in cattle: myths and misconceptions. Rangelands 19(3):10-13.

Kukel, C.F. and K.R. Jennings. 1994. Delphinium alkaloids as inhibitors of $\mu$-bungarotoxin binding to rat and insect neural membranes. Can. J. Physiol. Pharmacol. 72, 104-107.

Lang, D.G. and R.A. Smith. 1998. The chemical identification of plant toxins in ingesta and forage. p. 223-226. In: T. Garland and A.C. Barr (eds.), Toxic Plants and Other Natural Toxicants. CAB Intern., Oxon, U.K.

Lane, M.A., M.H. Ralphs, J.D. Olsen, F.D. Provenza, and J.A. Pfister. 1990. Conditioned taste aversion: potential for reducing cattle loss to tall larkspur. J. Range Manage. 43: 127-131.

Launchbaugh, K.L., F.D. Provenza, and E.A. Burritt. 1993. How herbivores track variable environments: response to variability of phytotoxins. J. Chem. Ecol. 19:1047-1056.

Leete, E. and J.O. Olson. 1972. Biosynthesis and metabolism of the hemlock alkaloids. J. Amer. Chem. Soc. 94:5472-5477.

Levin, D.A. 1976. Alkaloid-bearing plants: an ecogeographic perspective. Amer. Nat. 110:261-284

Lewin, L. 1931. Phantastica: Narcotic and Stimulating Drugs. Kegan Paul, Trench, Trubner, London.

Majak, W. 1993. Alkaloid levels in a species of low larkspur and their stability in rumen fluid. J. Range Manage. 46, 100-103. 
Majak, W., and M. Engelsjord. 1988. Levels of a neurotoxic alkaloid in a species of low larkspur. J. Range Manage. 41: 224-226.

Majak, W., R.E. McDiarmid, and M.H. Benn. 1987. Isolation and HPLC determination of methyllycaconitine in a species of low larkspur (Delphinium nuttallianum). J. Agr. Food Chem. 35: 800-804.

Majak, W., R.E. McDiarmid, W. Cristofoli, F. Sun, and M. Benn. 1992. Content of zygacine in Zygadenus venenosus at different stages of growth. Phytochem. 31:3417-3418.

Makeiff, D., W. Majak, R.W. McDiarmid, B. Reaney, and M.H. Benn. 1997. Determination of zygacine in Zygadenus venenosus (death camas) by image analysis on thin layer chromatography. J. Agr. Food Chem. 45:1209-1211.

Manners, G.D., K.E. Panter, and S.W. Pelletier. 1995. Structure-activity relationships of norditerpenoid alkaloids occurring in toxic larkspur (Delphinium) species. J. Nat Prod. 58: 863-869.

Manners, G.D., K.E. Panter, M.H. Ralphs, J.A. Pfister, and J.D. Olsen. 1993. The occurrence and toxic evaluation of norditerpenoid alkaloids in the tall larkspurs (Delphinium sp.). J. Agr. Food Chem. 41: 96-100.

Marsh, C.D. 1909. The loco-weed disease of the plains. USDA Bull. 112.

Marsh, C.D., A.B. Clawson, and H. Marsh. 1916. Larkspur poisoning of livestock USDA Bur. of Anim. Indust. Bull. 365.

Merrill, L.B. and J.L. Schuster. 1978. Grazing management practices affect livestock losses from poisonous plants. J. Range Manage. 31:351-354.

McDaniel, K. 1999. Controlling locoweed with herbicides. p. 52-54. In: T.M. Sterling and D.C. Thompson (eds.), Locoweed Research Update and Highlights. New Mexico Agr. Expt. Sta. Res. Rep. 730, Las Cruces, N.M.

Mickelsen, L.V., M.H. Ralphs, D.L. Turner, J.O. Evans, and S.A. Dewey. 1990. Herbicidal control of duncecap larkspur (Delphinium occidentale). Weed Sci. 38 153-157.

Molyneux, R.J. and L.F. James. 1982. Loco intoxication: indolizidine alkaloids of spotted locoweed (Astragalus lentiginosus). Sci. 216:190-191.

Molyneux, R.J. and L.F. James. 1990. Pyrrolizidine alkaloids in milk: thresholds for intoxication. Vet. Hum. Tox. 32:94-103.

Molyneux, R.J. and A.E. Johnson. 1984. Extraordinary levels of production of pyrrolizidine alkaloids in Senecio riddellii. $\mathrm{J}$ Nat. Prod. 47:1030-1032.

Molyneux, R.J. and M.H. Ralphs. 1992. Plant toxins and palatability to herbivores. J. Range Manage. 45:13-18.

Molyneux, R.J., L.F. James, K.E. Panter, and M.H. Ralphs. 1989. The occurrence and detection of swainsonine in locoweeds. $p$ 100-117. In: L.F. James, A.D. Elbein, R.J Molyneux, and C.D. Warren (eds.) Swainsonine and Related Glycosides Inhibitors. Iowa State Univ. Press, Ames, Ia.
Molyneux, R.J., A.E. Johnson, J.D. Olsen, and D.C. Baker. 1991. Toxicity of pyrrolizidine alkaloids from Riddell's groundsel (Senecio riddellii) to cattle. Amer. J. Vet. Res. 52:146-151.

Molyneux, R.J., R.A. McKenzie, B.M. O'Sullivan, and A.D. Elbein. 1995. Identification of the glycosides inhibitors swainsonine and calystegine $\mathrm{B}_{2}$ in Weir vine (Ipomoea sp. Q6 [aff calobra]) and correlation with toxicity. J. Nat. Prod. 58:878-886.

Nation P.N., M.H. Benn, S.H. Roth, and J.L. Wilkens. 1982. Clinical signs and studies of the site of action of purified larkspur alkaloid, methyllycaconitine, administered parenterally to calves. Can. Vet. J. 23: 264-266.

Nielsen, D.B., N.R. Rimbey, and L.F. James. 1988. Economic considerations of poisonous plants on livestock. p. 5-16. In: L.F. James, M.H. Ralphs, and D.B. Nielsen (eds.), The Ecology and Economic Impact of Poisonous Plants on Livestock Production. Westview Press, Boulder, Colo.

Olsen, J.D. 1978. Tall larkspur poisoning in cattle and sheep. J. Amer. Vet. Med. Assoc. 173:762-765.

Panter, K.E. 1983. Toxicity and Teratogenicity of Conium maculatum in swine and hamsters. Ph.D. Diss., Univ. Illinois, Urbana, Ill.

Panter, K.E. and L.F. James. 1989. Death camas-early grazing can be hazardous. Rangelands 11:147-149.

Panter, K.E. and L.F. James. 1995. Alkaloid toxicants and teratogens of plant origin. p. 145-154. In: D.L. Gustine and H.E. Flores (eds.), Phytochemicals and Health. Amer. Soc. Plant Physiol. Ser., Vol. 15. Rockville, Maryland

Panter, K.E. and R.F. Keeler. 1989. Piperidine alkaloids of poison hemlock (Conium maculatum). p. 109-132. In: P.R. Cheeke (ed.), Toxicants of Plant Origin. Vol. 1, Alkaloids. CRC Press, Boca Raton, Fla.

Panter, K.E., D.R. Gardner, and R.J. Molyneux. 1994. Comparison of toxic and teratogenic effects of Lupinus formosus, $L$. arbustus, and $L$. caudatus in goats. J. Nat. Toxins 3:83-93.

Panter, K.E., D.R. Gardner, and R.J. Molyneux. 1998b. Teratogenic and fetotoxic effects of two piperidine alkaloid-containing lupines ( $L$. formosus and L. arbustus) in cows. J. Nat. Toxins 7:131-140.

Panter, K.E., L.F. James, and D.R. Gardner. 1999. Lupines, poison-hemlock and Nicotiana spp: toxicity and teratogenicity in livestock. J. Nat. Toxins 8:117-134.

Panter, K.E., R.F. Keeler, and D.C. Baker. 1988b. Toxicoses in livestock from the hemlocks (Conium and Cicuta spp.). J. Anim. Sci. 66:2407-2413.

Panter, K.E., R.F. Keeler, and W.B. Buck. 1985. Congenital skeletal malformations induced by maternal ingestion of Conium maculatum (poison hemlock) in newborn pigs. Amer. J. Vet. Res. 46:2064-2066.
Panter, K.E., T.D. Bunch, R.F. Keeler, and D.V. Sisson. 1988a. Radio ultrasound observations of the fetotoxic effects in sheep from ingestion of Conium maculatum (poisonhemlock). Clin. Toxicol. 26:175-187.

Panter, K.E., R.F. Keeler, L.F. James, and T.D. Bunch. 1992. Impact of plant toxins on fetal and neonatal development: a review. J. Range Manage. 45:52-62.

Panter, K.E., M.H. Ralphs, R.A. Smart, and B. Duelke. 1987. Death camas poisoning in sheep: a case report. Vet. Hum. Toxicol. 29:45-48.

Panter, K.E., T.D. Bunch, R.F. Keeler, D.V. Sisson, and R.J. Callan. 1990. Multiple congenital contractures (MCC) and cleft palate induced in goats by ingestion of piperidine alkaloid-containing plants: reduction in fetal movement as the probable cause. Clin. Toxicol. 28:69-83.

Panter, K.E., D.R. Gardner, R.E. Shea, R.J. Molyneux, and L.F. James. 1998a. Toxic and teratogenic piperidine alkaloids from Lupinus, Conium, and Nicotiana species. p. 345-350. In: T. Garland and A.C. Barr (eds.), Toxic Plants and Other Natural Toxicants. CAB Intern., Oxon, U.K.

Panter, K.E., D.R. Gardner, C.C. Gay, L.F. James, R. Mills, J.M. Gay, and T.J. Baldwin. 1997. Observations of Lupinus sulphureus-induced "crooked calf disease". J. Range Manage. 50:587-592.

Pelletier, S.W. 1983. The nature and definition of an alkaloid. p. 1-31. In: S.W. Pelletier (ed.), Alkaloids- Chemical and Biological Perspectives. Vol. 1. John Wiley and Sons, New York, N.Y.

Penny, R.H.C. 1953. Hemlock poisoning in cattle. Vet. Rec. 65:669-670.

Pfister, J.A. 1999. Behavioral strategies for coping with poisonous plants. p. 45-59. In: K. Launchbaugh, K. Saunders, and J. Mosley, (eds.), Grazing Behavior of Livestock and Wildlife. Univ. Idaho For. Expt. Sta. Tech. Bull.

Pfister, J.A. and C.D. Cheney. 1998. Operant behavioral analysis of acute tall larkspur (Delphinium barbeyi) intoxication in cattle. Behav. 4:43-56.

Pfister, J.A. and D.R. Gardner. 1999. Consumption of low larkspur (Delphinium nuttallianum) by cattle. J. Range Manage. 52:378-383.

Pfister, J.A., R.J. Molyneux, and D.C. Baker. 1992. Pyrrolizidine alkaloid content of houndstongue (Cynoglossum officinale). J. Range Manage. 45:254-256.

Pfister, J.A., K.E. Panter, and G.D. Manners. 1994b. Effective dose in cattle of toxic alkaloids from tall larkspur (Delphinium barbeyi). Vet. Human Toxicol. 36:10-11.

Pfister, J.A., M.H. Ralphs, and G.D. Manners. 1988b. Cattle grazing tall larkspur on Utah mountain rangelands. J. Range Manage. 41: 118-122.

Pfister, J.A., J.B. Astorga, K.E. Panter, and R.J. Molyneux. 1993. Maternal locoweed exposure in utero and as a neonate does not disrupt taste aversion learning in lambs. Appl. Anim. Behav. Sci. 36:159-167. 
Pfister, J.A., G.D. Manners, D.R. Gardner, and M..H. Ralphs. 1994a. Toxic alkaloid levels in tall larkspur (Delphinium barbeyi) in western Colorado. J. Range Manage. 47: 355-358.

Pfister, J.A., K.E. Panter, G.D. Manners, and C.D. Cheney. 1994c. Reversal of tall larkspur (Delphinium barbeyi) toxicity with physostigmine. Vet. Human Toxicol. 36 : 511-514.

Pfister, J.A., D.C. Adams, M.J. Arambel, J.D. Olsen, and L.F. James. 1989. Subletha levels of toxic larkspur: effects on intake and rumen dynamics in cattle. Nutr. Rep. Intern. 40:629-636.

Pfister, J.A., G.D. Manners, D.R. Gardner, K.W. Price, and M.H. Ralphs. 1996a. Influence of alkaloid concentration on acceptability of tall larkspur (Delphinium spp.) to cattle and sheep. J. Chem. Ecol. 22:1147-1168

Pfister, J.A., G.D. Manners, M.H. Ralphs, Z.X. Hong, and M.A.Lane. 1988a. Effects of phenology, site and rumen fill on tall larkspur consumption by cattle. J. Range Manage. 41: 509-514.

Pfister, J.A., F.D. Provenza, G.D. Manners, D.R. Gardner, and M.H. Ralphs. 1997a Tall larkspur ingestion: can cattle regulate intake below toxic levels? J. Chem. Ecol. 23:759-777.

Pfister, J.A., B.L. Stegelmeier, C.D. Cheney, L.F. James, and R.J. Molyneux. 1996b. Operant analysis of chronic locoweed intoxication in sheep. J. Anim. Sci. 74:2622-2632.

Pfister, J.A., M.H. Ralphs, G.D. Manners, D.R. Gardner, K.W. Price, and L.F James. 1997b. Early season grazing by cattle of tall larkspur- (Delphinium spp.) infested rangeland. J. Range Manage. 50: 391-398.

Pfister, J.A., D.R. Gardner, K.E. Panter, G.D. Manners, M.H. Ralphs, B.L. Stegelmeier, and T.K. Schoch. 1999. Larkspur (Delphinium spp.) poisoning in livestock. J. Nat. Tox. 81-94.

Ralphs, M.H. 1987. Cattle grazing white locoweed: influence of grazing pressure and palatability associated with phenological growth stage. J. Range Manage. 40:330-332.

Ralphs, M.H. 1992. Conditioned food aversion: training livestock to avoid eating poisonous plants. J. Range Manage. 45:46-51.

Ralphs, M.H. 1997. Persistence of aversions to larkspur in naive and experienced cattle. J. Range Manage. 50: 367-370.

Ralphs, M.H. and R.J. Molyneux. 1989. Livestock grazing locoweed and the influence of swainsonine on locoweed palatability and habituation, p.39-49. In: L.F. James, A.D. Elbein, R.J. Molyneux, and C.D Warren (eds.) Swainsonine and Related Glycosides Inhibitors. Iowa State Univ. Press, Ames, Ia.

Ralphs, M.H. and J.D. Olsen. 1987. Alkaloids and palatability of poisonous plants. p. 78-83. In: USDA Forest Service Tech. Rep.

Ralphs, M.H. and J.D. Olsen. 1992. Prior grazing by sheep reduces waxy larkspur consumption by cattle. J. Range Manage. 45: 136-139.
Ralphs, M.H. and D.N. Ueckert. 1988. Herbicide control of locoweeds: a review. Weed Tech. 2:460-465.

Ralphs, M.H., J.E. Bowns, and G.D. Manners. 1991a. Utilization of larkspur by sheep. J. Range Manage. 44: 619-622.

Ralphs, M.H., J.O. Evans, and S.A. Dewey. 1992. Timing of herbicide applications for control of larkspurs. Weed Sci. 40: 264-269.

Ralphs, M.H., D. Graham, and L.F. James. 1994a. Social facilitation influences cattle to graze locoweed. J. Range Manage. 47:123-126.

Ralphs, M.H, L.F. James, and J.A. Pfister. 1986. Utilization of white locoweed (Oxytropis sericea Nutt.) by range cattle. J. Range Manage. 39:344-347.

Ralphs, M.H., G.D. Manners, and D.R. Gardner. 1998. Toxic alkaloid response to herbicides used to control tall larkspur. Weed Sci. 46:116-119.

Ralphs, M.H., L.V. Mickelsen, and D.L. Turner. 1987. Cattle grazing white locoweed: diet selection patterns of native and introduced cattle. J. Range Manage. 40:333-335.

Ralphs, M.H., K.E. Panter, and L.F. James. 1990. Feed preferences and habituation of sheep poisoned by locoweed. J. Anim. Sci. 68:1354-1362.

Ralphs, M.H, K.E. Panter, and L.F. James. 1991b. Grazing behavior and forage preference of sheep with chronic locoweed toxicosis suggest no addiction. J. Range Manage. 44:208-209.

Ralphs, M.H., T.D. Whitson, and D.N. Ueckert. 1991d. Herbicide control of poisonous plants. Rangelands 13:73-77.

Ralphs, M.H., D. Graham, M.L. Galyean, and L.F. James. 1997a. Creating aversions to locoweed in naive and familiar cattle. J. Range Manage. 50:361-366.

Ralphs, M.H., D. Graham, L.F. James, and K.E. Panter. 1994b. Locoweed effects on a calf crop. Rangelands 16:35-37

Ralphs, M.H., D. Graham, R.J. Molyneux, and L.F. James. 1993. Seasonal grazing of locoweeds by cattle in northeastern New Mexico. J. Range Manage. 46:416-420.

Ralphs, M.H., L.F. James, D.B. Nielsen, and K.E. Panter. 1984. Management practices reduce cattle loss to locoweed on high mountain range. Rangelands 6(4):175-177.

Ralphs, M.H., J.D. Graham, G. Duff, B.L. Stegelmeier, and L.F. James. 2000. Impact of locoweed poisoning on steer weight gains. J. Range Manage. 53:86-90.

Ralphs, M.H., L.F. James, D.B. Nielsen, D.C. Baker, and R.J. Molyneux. 1988. Cattle grazing Wahweap milkvetch in southeastern Utah. J. Anim. Sci. 66:3124-3130.

Ralphs, M.H., G.D. Manners, J.A. Pfister, D.R.Gardner, and L.F. James. 1997b. Toxic alkaloid concentration in tall larkspur species in the western United States. J. Range Manage. 50: 497-502.

Ralphs, M.H., D.L. Turner, L.V. Mickelsen, J.O. Evans, and S.A. Dewey. 1991c. Herbicides for control of tall larkspur (Delphinium barbeyi). Weed Sci. 38: 573-577.
Robinson, T. 1979. The evolutionary ecology of alkaloids. p. 413-448. In: G.A. Rosenthal and D.H. Janzen. (eds.), Herbivores: Their Interaction with Secondary Plant Metabolites. Academic Press, New York, N.Y.

Roitman, J.N. and K.E. Panter. 1995. Livestock poisoning caused by plant alkaloids. p. 53-124. In: M. Blum (ed.), The Toxic Action of Marine and Terrestrial Alkaloids. Alaken, Inc., Ft. Collins, Colo.

Schmeller, T., M. Sauerwein, F. Sporer, M. Wink, and W.E. Muller. 1994. Binding of quinolizidine alkaloids to nicotinic and muscarinic acetylcholine receptors. J. Nat. Prod. 57:1316-1319.

Sharrow, S.H., D.N. Ueckert, and A.E. Johnson. 1988. Ecology and toxicology of Senecio species with special reference to Senecio jacobaea and Senecio longilobus. p. 181-196. In: L.F. James, M.H. Ralphs, and D.B. Nielsen (eds.), The Ecology and Economic Impact of Poisonous Plants on Livestock Production. Westview Press, Boulder, Colo.

Smith, G.S., K.W. Allred, and D.E. Kiehl. 1992. Swainsonine content of New Mexico locoweeds. Proc. West. Sec. Amer. Soc. Anim. Sci. 43:405-407.

Smith, L.W., and C.C.J. Culvenor. 1981. Plant sources of hepatotoxic pyrrolizidine alkaloids. J. Nat. Prod. 44:129-152.

Stanford, K. T.A. McAllister, B.M. Lees, and K.J. Cheng. 1996. Comparison of sweet white lupin seed, canola meal, and soybean meal as protein supplements for lambs. Can. J. Anim. Sci. 76:215-219.

Stegelmeier, B.L., D.R. Gardner, L.F. James, and R.J. Molyneux. 1996. Pyrrole detection and the pathologic progression of Cynoglossum officinale (houndstongue) poisoning in horses. J. Vet. Diagn. Invest. 8:81-90.

Stegelmeier, B.L., L.F. James, K.E. Panter, and R.J. Molyneux. 1995b. Serum swainsonine concentration and $\propto$-mannosidase activity in cattle and sheep ingesting Oxytropis sericea and Astragalus lentiginosus (locoweeds). Amer. J. Vet. Res. 56:149-154.

Stegelmeier, B.L., R.J. Molyneux, A.D. Elbein, and L.F. James. 1995a. The lesions of locoweed (Astragalus mollissimus), swainsonine, and castanospermine in rats. Vet. Path. 32:289-298.

Stegelmeier, B.L., M.H. Ralphs, D.R. Gardner, R.J. Molyneux, and L.F. James. 1994. Serum $\propto$-mannosidase activity and the clinicopathologic alterations of locoweed (Astragalus mollissimus) intoxication in range cattle. J. Vet. Diagn. Invest. 6:473-479.

Stegelmeier, B.L., L.F. James, K.E. Panter, D.R. Gardner, M.H. Ralphs, and J.A. Pfister. 1998a. Tissue swainsonine clearance in sheep chronically poisoned with locoweed (Oxytropis sericea). J. Anim. Sci. 76:1140-1144.

Stegelmeier, B.L., K.E. Panter, J.A. Pfister, L.F. James, G.D. Manners, D.R. Gardner, M.H. Ralphs, and J.D. Olsen. $1998 b$. Experimental modification of larkspur (Delphinium spp.) toxicity. p. 205-210. In: 
T. Garland and A.C. Barr (eds.), Toxic Plants and Other Natural Toxicants. CAB Intern., Oxon, U.K.

Tokarnia, C.H., J. Dobereiner, and P.V. Peixoto. 1992. Poisonous plants of Brazil. p. 63-70. In: L.F. James, R.F. Keeler, E.M. Bailey, Jr., P.R. Cheeke, and M.P. Hegarty (eds.), Poisonous Plants. Iowa State Univ. Press, Ames, Ia.

Torell, L.A., L.P. Owen, and J.D. Graham. 1999b. Healing locoweed-poisoned cattle before sale decreases economic losses. $\mathrm{p}$. 80-81. In: T.M. Sterling and D.C. Thompson (eds.), Locoweed Research: Update and Highlights. New Mexico Agr. Expt. Sta. Res. Rep. 730, Las Cruces, N.M.

Torell, L.A., K. McDaniel, L.P. Owen, and J.D. Graham. 1999a. The economic value of having a locoweed-free area. p. 82-83. In: T.M. Sterling and D.C. Thompson (eds.), Locoweed Research: Update and Highlights. New Mexico Agr. Exp. Sta. Res. Rep. 730 , Las Cruces, N.M.
Van Damm, N.M., R. Verpoorte, and E. Van der Meijden. 1994. Extreme differences in pyrrolizidine alkaloid levels between leaves of Cynoglossum officinale. Phytochem. 37:1013-1016.

Van Kampen, K.R. and L.F. James. 1970. Pathology of locoweed (Astragalus lentinginosus) poisoning in sheep: sequential development of cytoplasmic vacuolation in tissues. Path. Vet. 7:503-508.

Velastegui, W., G.S. Smith, T.S. Edrington, M. Stavanja, D.E. Kiehl, and G.M. Southward. 1992. Swainsonine content and comparative toxicity of seedpods, leaves, and stems from halfmoon locoweed Astragalus allochrous. Proc. West. Sec. Amer. Soc. Anim. Sci. 43:403-404.

Wachenheim, D.E., L.L. Blythe, and A.M. Craig. 1992. Characterization of rumen bacterial pyrrolizidine alkaloid biotransformation in ruminants of various species. Vet. Hum. Tox. 34:513-517.
Williams, M.C. and E.H. Cronin. 1981. Ten-year control of western false hellebore (Veratrum californicum). Weed Sci. 29:22-23.

Wink, M., C. Meisner, and L. Witte. 1995. Patterns of quinolizidine alkaloids in 56 species of the genus Lupinus. Phytochem. 38:139-153.

Winter, C.K. and H.J. Segall. 1989. Metabolism of pyrrolizidine alkaloids. p. 23-40. In: P.R. Cheeke (ed.), Toxicants of Plant Origin. Vol. 1, Alkaloids. CRC Press, Boca Raton, Fla. 